\title{
Zeynel Besim Sun'un Çakıcı Mehmet Efe Romanında Başkahraman Üzerine Tespitler ${ }^{1}$
}

\section{Halil SAĞLAM²}

APA: Sağlam, M. H. (2018). Zeynel Besim Sun'un Çakıcı Mehmet Efe Romanında Başkahraman Üzerine Tespitler. RumeliDE Dil ve Edebiyat Araşttrmaları Dergisi, (12), 184-208. DOI: 10.29000/rumelide.472765

\section{$\ddot{\mathbf{O} z}$}

Çakıcı Mehmet Efe romanı 1934 yılında İzmir Ticaret Postası Gazetesi'nde tefrika halinde yayımlanmıştır. Roman, Çakıcı Mehmet Efe hakkında yazılan ilk roman olması ve dönemin sosyal, siyasal ve kültürel özelliklerini yansıtması açısından önemlidir. Çakıcı Mehmet Efe'nin yaşadığı Ege köylerinde yapılan derleme çalışması üzerine kurgulanan romanda, vaka örgüsüyle ilgili ansiklopedik bilgiler ve fotoğraflar da bulunmaktadır. Çakıı Mehmet Efe hakkında bir romanı bulunan Yaşar Kemal de bu romanın Çakırcalı üstüne yazılmış en ilginç kitaplardan bir olduğunu ifade etmektedir. Romanın bir başka özelliği de Ege'de eşkıyalık ve Çakııı Mehmet Efe hakkında yapılan akademik çalışmalarda kaynak olarak kullanılmasıdır. Bu çalışmanın temel amacı Çakıcı Mehmet Efe'nin soylu eşkıya tipojisine uyan ve aykırı düşen karakter özelliklerini tespit etmektir. Nitel araştırma metodunun uygulandığı çalışmada elde edilen bulgular, reel tarihî kaynaklarla karşılaştırılmıştır. Yapılan araştırma sonucunda Çakıcı Mehmet Efe'nin soylu eşkıya tipolojisiyle örtüşen vasıflar taşımakla birlikte zamanla bu vasıfları yitirdiği tespit edilmiştir. İçlerinde çocuk, kadın ve askerlerin de bulunduğu binden fazla insanı acımasızca öldüren Çakıcı Mehmet Efe'nin Türk romanlarında, sinemalarında ve tiyatrolarında saygıyla ve övgüyle anlatılması bir eleştiri konusudur. Cumhuriyet'in ilk yllarından beri devam eden bu olumlu algının yeniden değerlendirilmesi önem arz etmektedir.

Anahtar kelimeler: Çakıcı Mehmet Efe, soylu eşkıya, Zeynel Besim Sun.

\section{Evaluations on The Main Character in The Novel Entitled Çakici Mehmet Efe of Zeynel Besim Sun}

\begin{abstract}
The novel of Çakıcı Mehmet Efe is published by İzmir Ticaret Postasi newspaper in episodes in 1934. The novel is valuable as it is the first novel written about Çakıcı Mehmet Efeand reflects its era's social, political and cultural aspects. The novel is fictionalised based on the collected work from the villages where Çakıcı Mehmet Efe lived and incorporates encyclopedic knowledge and pictures about the storyline. Yaşar Kemal, who has a novel about Çakıcı Mehmet Efe, expresses that this novel is one of the most interesting books written on Çakırcall. Another aspect of the novel is that it is being used as a source for academic studies regarding Çakıcı Mehmet Efe and banditry in Aegean region (of Turkey). The primary objective of this study is to identify the characteristic features in and out of line with the stereotype of heroic bandit. The results obtained by qualitative analysis are compared against real historical sources. As a result of research undertaken, it has been identified that despite
\end{abstract}

Bu makale 9-11 Mart 2018 tarihlerinde toplanan Uluslararası IKSAD Sosyal Bilimler Kongresi'de sunulan Zeynel Besim Sun'un Çakırcalı Mehmet Efe Romanında Başkahramanın Karakteristlik Özellikleri başlıklı bildirinin genişletilmiş halidir. Mardin.

2 Dr. Öğr. Üyesi, Siirt Űniversitesi, Eğitim Fakültesi, Türkçe ve Sosyal Bilimler Eğitimi Bölümü, Türkçe Eğitimi ABD, mhalil.saglam@gmail.com, ORCID ID: 00oo-0001-7557-7021 [Makale kayıt tarihi: 29.6.2018-kabul tarihi:6.10.2018] 


\begin{abstract}
Çakıcı Mehmet Efehas the characteristic features in line with the stereotype of heroic bandit, over time, he loses these features. Çakıcı Mehmet Efe who murdered more than a thousand of people including children, women and soldiers was narrated respectfully and admirably, which is a subject of criticism.It is noteworthy to note that the favourable perception has been ongoing since the beginning of Turkish republic need to be readdressed.
\end{abstract}

Key words: Çakıcı Mehmet Efe, heroic bandit, Zeynel Besim Sun.

\title{
1. Giriş
}

\subsection{Araştırmanın Amacı ve Önemi}

Çakıcı Mehmet Efe'nin yaşadığı köy ve kasabalarda yapılan derleme çalışmalarına ve döneme ait resmî bilgi ve belgelere bakıldığında Çakıcı'nın birbirine zıt, farklı karakter özellikler taşıdığı görülmektedir. Ege Bölgesi'nde, Çakıcı Mehmet Efe'nin yolda kalanlara yardım ettiğine, hastalara ilaç parası verdiğine, fakir köylüleri evlendirdiğine, köylere yol, köprü, çeşme ve cami gibi imar hizmetleri getirdiğine, köylüleri eşkıyalara, zalim vergi memurlarına ve müfrezelere karşı koruduğuna dair rivayetler bulunmaktadır. Fakat aynı bölgede Çakıcı'nın haydutluk yaptığına, posta soyduğuna, kaçakçılık yaptığına, fabrika yaktığına, çocuk, kadın ve asker demeden yüzlerce masum insanı acımasızca öldürdüğüne dair olaylar da anlatılmaktadır. Çakıcı Mehmet Efe'nin olumlu ve olumsuz yönlerine rağmen Türk romanlarında, sinemalarında ve tiyatrolarında bir halk kahramanı olarak tanıtılması tartışma konusudur. Cumhuriyetin ilanından günümüze kadar devam kültür politikasında Çakıcı Mehmet Efe algısı sürekli olumlu olmuştur.

Bu çalışma, Osmanlı Devleti’nin dağılma sürecinde en önemli çete liderleri arasında bulunan Çakıcı Mehmet Efe'yi birbirine zıt farklı yönleriyle tanıtmayı amaçlamaktadır. Araştırma, Cumhuriyetin ilk yıllarından beri devam eden yanlış bir algıyı değiştirmeyi hedeflediği için önem arz etmektedir. Zeynel Besim Sun'un romanı kurmaca bir eser olduğu için objektifliği tartışma konusu olabilir. Fakat roman, Çakıcı Mehmet Efe hakkında birinci derecede kaynaklardan yararlanılarak kaleme alındığı ve vaka örgüsüyle ilgili ansiklopedik bilgiler ve fotoğraflar içerdiği için realisttir. Ayrıca romanın vaka örgüsü, şahıs kadrosu, objektif ve gerçek bilgilerle örtüşmektedir. Tarihî romanların reel bir kaynak olmamakla birlikte vaka zamanının sosyal, kültürel ve ekonomik şartlarını ve kahramanların soyo-psişik özelliklerini belirli ölçüde yansıttığı bilinen bir gerçektir. "Tarih metni oluşturulurken gerçekte yaşanan tarihten, tarihsel kayıt ya da belgelere, oradan yeniden kurulan tarihsel olguya, sentez ve tahkiye ile metne gelinir. Romancı ise, tarihçinin sunduğu malzemeyi aynen kullanır" (Çelik, 2002:113). Tarihî romanların tarihî belgelerden en önemli farkları kahramanların aşk, ihtiras, kin ve nefret gibi romantik yanlarını yansıtmalarıdır. Tarihe mâl olmuş önemli şahsiyetlerin iç dünyalarını, aşk maceralarını kısacası tüm insani yönlerini romanlarda görmek mümkündür. Sun'un bu tarihî romanı başkahraman Çakıcı Mehmet Efe'nin psikolojik özelliklerini yansıtmaktadır. Çakıcı Mehmet Efe'nin reel tarihî kaynaklarda yer almayan birçok karakteristik özellikleri romanda yer almaktadır. Çakıcı Mehmet Efe hakkında yazılan bu ilk roman, aynı zamanda Türk eşkıyalık tarihî için de önemli bir kaynaktır.

\subsection{Araștırma Problemi}

Çakııı Mehmet Efe, adına kültürel etkinlikler düzenlenecek kadar saygın bir halk kahramanı mı yoksa içlerinde çocuk, kadın ve askerlerin de bulunduğu binlerce insanı acımasızca öldüren bir eşkıya mıdır? 
Zeynel Besim Sun'un Çakıcı Mehmet Efe romanının edebî ve akademik değeri nedir? Bu araştırma bu problem cümlelerini çözümlemeye yönelik yapılmıştır.

\title{
1.3. Araştırmanın Sinırlılıkları
}

Türk edebiyatında içlerinde Sabahattin Ali ve Yaşar Kemal'in de bulunduğu farklı yazarların Çakıcı Mehmet Efe hakkında kaleme aldıkları romanlar bulunmaktadır. Çakıcı Mehmet Efe hakkında yazılan ilk roman Zeynel Besim Sun'a aittir (1934) Bu çalışma temelde Zeynel Besim Sun'un Çakıcı Mehmet Efe romanının analiziyle sınırlıdır. Roman, kendisinden sonra kaleme alınan birçok Türk romanı ve Türk eşkıya tarihi için önemli bir kaynaktır. Ege Bölgesinde yapılan derleme çalışması üzerine kurgulanan roman, Çakıcı Mehmet Efe'nin karakter analizi bağlamında incelenmiştir. Çalışmada romanın vaka örgüsü, şahıs kadrosu, zaman ve mekân unsurları değerlendirilmemiştir. Romanda elde edilen bulgular reel tarihî kaynaklarla karşılaştırılmıştır. Bu kaynaklar Sabri Yetkin’in Ege’de Eşkıyalar kitabı, Halil Dural'ın Bize Derler Çakurcalı 19. ve 20. Yüzyılda Efeler kitabı ve Ercan Uyanık’n Çakırcalı Mehmet Efe Kronolojisi makalesiyle sinırlı tutulmuştur.

\subsection{Efelik, Eşkıyalık ve Soylu ve Adi Eşkıyalık kavramları Üzerine}

Efelik ve eşkıyalık Türk kültür tarihinin bir realitesidir. Bugün Anadolu'dan Orta Asya’ya; Orta Doğu'dan, Kafkasya'ya; İran'dan Balkanlar'a kadar çok geniş Türk coğrafyasında efelerin ve eşkıyaların efsaneleşmiş hayat maceraları anlatılmaktadır. Türk edebiyatında Dadaloğlu, Köroğlu, Hekimoğlu İsmail, Yalnız Efe ve Çakıcı Mehmet Efe gibi halk kahramanları hakkında kaleme alınan şiirler, türküler, roman ve hikâyeler efelik olgusunun halk kültüründe karşıladığı anlam zenginliğini göstermesi açısından önemlidir. Efelerin ve eşkıyaların ortak özellikleri, "belli bir yerde baskı görmeleri sonucunda suç işleme, kanunlara karşı geldikleri için dağa çıkma, takip edilme ve bu nedenle farkh yerlerde dolaşma, bir grup oluşturma, yerel ve merkezi güçlerle çatışma ve sonuçta ya affedilme veya öldürülmeleridir" (Ekici, 2008:2). Türk dilinde efe ve eşkıya sembollerinin farklı anlamları olmalarına rağmen anlatılarda iç içe kullanması efelerin zamanla değişen hayat tarzlarından kaynaklanmıştır.

\begin{abstract}
"Efe sözcüğünün eski Türkçe aba-kardeşten geldiği söylenir. Ege bölgesindeki köy, yiğit delikanlılarına verilen addır. Anadolu köylerinde ise ağabey, efendi anlamında hitaptır" (Şapolyo, 1991:18)“Efe, doğruluk, arkadaşlık, vatana bağlılık, vefakarlık simgesi olarak tanınmaktadır... Efe, zulme, işkenceye, barbarlığa, üzüntü ve sıkıntılara yıllarca katlanan Aydın ilinin ve Ege'nin bölge karakterini taşıyan insandır. Birbirlerine çok bağlıdırlar. Osmanlı devrinde zaman zaman devlete başkaldırıp dağa çıkanları olmuştur. Zenginden aldığını yoksula dağıtan, çıplak gelinlere çeyiz düzen efelerin öyküsü halk dilinde hâlâ dolaşır durur" (Özbilgin, 2003:25).
\end{abstract}

Temeli Selçuklulara dayanan efe teşkilatının ilk kurulma amacı sınır bölgelerinde güvenliği sağlamaktır (Üsküp, 1992:71). Merkezi otoriteye bağlı olarak görev yapan efelerin kendi içlerinde belli bir emirkomuta zinciri ve hiyerarşik yapısı bulunmaktadır. Bu yapı içerisinde yukarıdan aşağıya doğru efe, zeybek ve kızan şeklinde bir sıralama vardır (Veren, 2014:1). Efe, teşkilatın kurucu lideri olup cesaret ve kuvvetiyle teşkilat üyeleri üzerinde baskın bir role sahiptir. Efeleri, zeybeklerden ve kızanlardan ayıran özellikleri fazlasıyla cesur ve şöhretli olmalarıdır. Berrak Taranç Arusan'ın tespitiyle de: “Zeybekler cesur, mert, acizleri koruyan iseler ve yaptıklar işlerle ün kazanmış kişilerse onlara efe denir" (Arusan, 1988:12). Merkezi ve yerel yönetimlerin desteğiyle hareket eden efeler, kırsal bölgelerde yaşanan sosyal ve ekonomik sorunların çözümünde aktif rol alırlar. Efelik teşkilatının ana unsurlarından bir diğeri olan zeybekler ise doğrudan efeye bağlı olup kızanlardan sorumlu kol beyleridir. Türkmenlerin Batı Anadolu'ya yerleşmelerinden sonra ortaya çıan zeybeklerin asıl görevi, yol kontrolü yapmak ve kervansarayların güvenliğini sağlamaktır. Teşkilat üyeleri bu hizmetlerinin karşılı̆̆ı olarak yol 
güzergâhlarında karşılaştıkları bazı yolculardan ve ticaret kervanlardan para alırlar. Zeybekler aynı zamanda derbentlik yaparak ve ayanların maiyetlerinde bulunarak da geçimlerini sağlarlar (Veren, 2014:1). Efelik teşkilatının en alt biriminde görev alan kızanlar ise zeybeklere karşı sorumlu olup birinci derecede efeye bağlıydılar. Batı Anadolu'da erkek çocuklar için kullanılan "kızan" sözcüğü, "silahlı köy delikanlısı" anlamına gelmektedir (Türkçe Sözlük, 2011:1435). Efenin ve zeybeklerin talimatlarını başarıyla yerine getiren, iyi silah kullanan ve zekâsıly dikkat çeken kızanlar düzenlenen özel bir törenden sonra zeybek unvanını alırlar. Teşkilat lideri, zeybeklerin ve kızanların iyi bir nişancı, cesur bir asker olmalarını istediği kadar, namuslu ve adaletli olmalarını da ister. Sosyal adalete ve kültürel değerlere önem veren efeler, merkezi ve yerel yöneticilerin işlerini kolaylaştırmak ve iç güvenliğin tesisinde onlara yardım etmek için ellerinden gelen gayreti gösterirler.

Büyük Selçuklu Devleti'nin tarih sahnesinde bulunduğu dönemde (1040-1157) sınır bölgelerini korumak için kurulan efelik teşkilatıyla ilgili olumlu algı zamanla değişir. Cesur, delikanlı, yiğit ve yardımsever insanlar için kullanılan efe simgesi zamanla eşkıya simgesiyle birlikte kullanılmaya başlar. Ticaret kervanlarının önünü kesip onlardan zorla para alan teşkilat üyelerinin sayısı arttıkça Anadolu'da efelere karşı güven azalır. Ayrıca kanun kaçaklarının korunması, merkezi yönetimin emirlerine itaatsizlik ve zengin köylülerin fidye karşılı̆̆ında dağa kaldırılması da efelerin itibar kaybına sebep olmuştur. Cesaretleri ve mertlikleriyle anılan efelerin eşkıya sıfatıyla anılmaya başlanması bu tip eylemlerinden sonra olmuştur.

Türkçede "eşkıya" simgesi dağda, kırda, yol kesen hırsızlar, haydutlar için kullanılmaktadır (Türkçe Sözlük, 2011: 825). Arapça kökenli bir sözcük olan eşkıyanın mastarı "şeka'dır" ve "şâki” öznesinin çoğulundan türetilir (Yetkin, 1996:7). Anadolu'da şöhretli eşkıyaların olumsuz yanlarıly birlikte fakir köylülere yardım etmek ve güçlüye karşı güçsüzleri korumak gibi olumlu yanları da bulunmaktadır. Bu sebeple Anadolu'da eşkıyalık algısı olumlu ve olumsuz olmak üzere iki tiptir:

"Bunlardan ilki, eşkıyalığı yücelten, bir tür direniş olarak gören, toplum ve halk adına haklı bir hareket gibi kabul eden romantik görüş; ikincisi ise, eşkıyalığı, devletin çatısı altında, devlete rağmen hareket eden, halkla çatışan ve devletten ziyade halka zarar veren kişi ve grupların yasadışı hareketi olarak kabul eden görüştür" (Gözütok, 2011:50).

Ege Bölgesi’nde meşhur efeler hakkında yapılan derleme çalışmalarında anlatıcıların efe ve eşkıya sembollerini iç içe kullanmaları bu iki farklı bakış açısından kaynaklanmaktadır. Kimilerine göre halk kahramanı kimilerine göre ise acımasız ve adaletsiz bir çete liderleri olarak kabul edilen eşkyyalar için "soylu eşkıya" "soylu soyguncu" veya "toplumsal eşkıya" tanımlaması da kullanılmaktadır. Marxist iktisadî ve toplumsal tarih anlayışının temsilcileri arasında bulunan Eric J. Hobsbawm bu konuda şu bilgileri verir:

“Toplumsal eşkıya, lord ve devlet tarafından suçlu sayılan ama köylü toplumu içerisinde varlığını sürdüren ve köylüler tarafından kahraman, yenilmez, intikam alan, adalet için dövüşen, belki de özgürlüğün lideri olarak görülen ve her durumda saygı duyulan, yardım edilen ve desteklenen firari köylülerdir" (Hobsbawm, 1997:12).

Soylu eşkıyalar sıradan çete liderlerinden farklı olarak saygın bir toplumsal rol üstlenirler. Bu tip eşkıyalar, cesur, adaletli ve yardımsever yönleriyle merkezi otorite boşluğunun olduğu kırsal alanlarda hükümet otoritesine karşı alternatif bir güç olarak kabul edilirler. Eşkıyalığın tarihî, edebî ve içtimaî yönünü inceleyen akademik çalışmalarda soylu eşkıyalı̆̆ın tipolojik özellikleri genelde Hobsbawm'ın Eşkıyalar adlı kitabı referans gösterilerek aktarılmaktadır. Hobsbawm, Avrupa, Amerika ve Asya ülkelerinde eşkıyalık kurumu üzerine yaptığı araştırmalar sonucunda kaleme aldığg kitabında eşkıyaları 
birkaç kategoride değerlendirir. Soylu eşkıyalık kategorisinde değerlendirdiği eşkıyaların özelliklerini şu şekilde özetler:

"1. Soylu soyguncu kanun kaçakçılığı, yaşantısına bir suç işleyerek değil bir adaletsizliğin kurbanı olarak ya halkın göreneklerine göre bir suç oluşturmayan, ama otoritenin suç kabul ettiği bir eylemde bulunmaktan dolayı zulüm görmekle başlar.Öldürmede ve zor kullanmada ölçülü olma soylu eşkıyanın bir imgesidir.

2. O, yanlışları düzeltir.

3. $\mathrm{O}$, zenginden yoksula vermek için alır

4. O, yalnız kendisini savunmak veya intikam almak için adam öldürür.

5. O, eğer ömrü vefa ederse halkına şerefli bir vatandaş olarak geri döner.

6. Halkı ona hayranlık duyar, yardım eder ve destekler.

7. O da herkes gibi birgün ölür, ama topluluğun hiçbir üyesi ona karşı otoritelerle işbirliğine giremeyeceğine göre ölümü ihanet yüzündendir.

8. $\mathrm{O}$, en azından teoride efsunlu ve gizemlidir.

9. Adaletin kaynağı olan kralın veya imparatorun değil, ama yalnızca yerel genetrynin (İngiltere'deki orta sınıf halk ), rahiplerin ve diğer zalimlerin düşmanıdır” (Hobsbawm, 1997:43).

Haksızlığa uğrayan, emeği sömürülen, sosyal ve psikolojik baskı gören her insan, doğası gereği haksızlı̆ga ve zulme karşı eylemsel bir tepkide bulunmak ister. Fakat mevcut otoritenin tehditleri ve baskısı karşısında hakkını savunma iradesini ve cesaretini gösteremeyebilir. Özellikle feodal yapının hâkim olduğu toplumlarda ezilen köylü ve işçi sınıfının haklarını savunma ihtimali ve imkânı çok zayıftır. Çünkü bu tip toplumlarda mevcut otoriter güce itaat etmeyen veya isyan eden alt sınıf tabaka en ağır şekilde cezalandırılır. Cezalandırılmaktan korkmayarak mevcut otoritenin baskılarına karşı direnen kişiler birer halk kahramanı olarak kabul edilirler. Bu kişiler gerçekte erdemli ve ülkücü kişiler olmasalar bile halk onları hayallerinde yüceltir ve haklarında birer efsane türetir. Moran'ın tespitine göre bu efsaneler de birbirine benzemektedir, çünkü ezilen halkın, zulüm karşısında susup boyun eğmek yerine başkaldıran zalimlerden intikam alan, adalet dă̆ıtan kahramanlara gereksinimi vardır. Halk, adalet ve eşitlik umudunu karşılayacak bir kahraman çıkmasa da onu iç dünyasında yaşatır ve ölümsüzleştirir. Bu sebeple dünyanın farklı ülkelerinde rastlanan soylu eşkıya tip aynı özelliği gösterir (Moran,2012:105). Hobsbawm'ın kitabında soylu eşkıya tiplemesine örnek olabilecek hayatı efsaneleşmiş birçok halk kahramanı bulunmaktadır. Bu cesur halk kahramanları kanun karşısında suç işleseler bile halkın nazarında yüceltilmiş erdemli kişilerdedir. Çünkü onlar sosyal adaletsizliklerin ve baskıların sonucunda suç işlemeye mecbur bırakılır. Rousseau felsefesine göre de insanoğlunun kötülüğü ve suç işlemesi toplumsal hayattan kaynaklanır. Toplum, suça zemin hazırlar, suçlu ise duygusal bir tepki olarak o suçu işlemek zorunda kalır. İnsanın doğasında suç işleme ve kötülük yapma gibi olumsuz eğilimler yoktur. İnsanı suç işlemeye kötülük yapmaya mecbur kılan eğilimler sonradan ortaya çıkmıştır (Rousseau,2010:91). Bu duygusal eğilimlerin temel kaynağı da sosyal hayattaki sınıf farklılıkları ve eşitsizliklerdir. Rousseau, İnsanlar Arasında Eşitsizliğin Kaynağı eserinde iki tip eşitsizlikten söz eder. Bunlardan birincisi insanlar arasındaki yaş, sağllk, zekâ ve ruhsal nitelikler gibi doğuştan gelen farklılıklara dayalı eşitsizliklerdir. İnsanın yaratılışından kaynaklanan bu eşitsizlikler iradesi dışında gerçekleşir. İkinci tip eşitsizlik ise politik ve manevidir. İnsanların toplumsallaşmasından sonra ortaya çıkan politik eşitsizlik tamamıla uzlaşma, irade ve onaylamadır. Rousseau'nun tanımlamasıyla "bu ikincisi kimilerinin başkalarının zararına yararlandiğı, örneğin onlardan daha zengin, daha itibarl olmak ya da onlara boyun eğdirmiş olmak gibi ayrıcalkklardan ibarettir" (Rousseau,2006:83). Politik eşitsizlik, zamanla sosyal sınıf tabakalarını oluşturmuştur. Üst sınıf tabakanın mülkiyeti ve ayrıcalıkları arttıkça alt sınıf tabaka üzerindeki baskısı artar böylece politik 
eşitsizlik derinleşir. Rousseau'nun tespitlerine göre sosyal hayattaki çatışmaların en önemli sebeplerinden biri sınıflar arasındaki ekonomik eşitsizliklerdir. Dünyanın farklı ülkelerinde görülen soylu eşkıyaların ortaya çıma nedenlerinden birini de politik eşitsizlikte aramak gerekir.

Bütün toplumlarda egemen iradeyi güçlü tutmak üzere kurgulanmış kanun sistemine ve bu sistemin olanaklarıyla yoksul üretici sınıfı sömüren burjuva sınıfına karşı başkaldırı kaçınılmazdır. Azınlıklara karşı çoğunluğu temsil eden direnişçiler hareket alanlarını genişletmek, burjuvaları koruyan yasaların hükmü altına girmemek için mevcut otoriteye karşı bir isyan hareketi başlatırlar. Rousseau, Fransa'da ayrıcalıklı sınıfın gücünü, sistemin bu sınıflara verdiği politik baskı olanaklarını yıkmak için sosyal alanların dışına çıkan direnişçiler için soylu vahşi kavramını kullanır (Moran, 2012:38). Soylu vahşilerin kanun kaçağı zalim vahşilerden farkı, kanun kaçağı olarak yaşadıkları dağlarda adaletli ve merhametli olmaya çalışmalarıdır. Soylu vahşilerin kendilerine göre farklı bir adalet anlayışları vardır. Zengin köylülerin mallarını alıp fakir köylülere dağıtmakla, çete mahkemelerinde yargıladıkları köylüleri cezalandırmakla ve ezilen köylüleri merkezi otoriteye karşı korumakla halkın sevgi ve saygısını kazandıklarına inanırlar. Fakir Köylülerin sosyal, ekonomik ve psikolojik desteğini alan soylu eşkıyalar, hâkim oldukları yataklarda fakirlerin mallarına dokunmazlar. Çünkü fakir köylülerin temel ihtiyaçlarını karşılayacak mallarının dışında soylu vahşilere verebilecekleri herhangi bir şeyleri yoktur. Ayrıca soylu eşkıyalar köylerde toprak ağalarına ve fabrika sahiplerine köprü, yol, çeşme ve cami yaptırarak fakir köylülerin desteğini alırlar. Toprak ağaları, patronlar ve muhtarlar, kimi zaman can korkusuyla kimi zaman da menfaat sağlamak amacıyla soylu eşkıyaların taleplerini karşılarlar. Soylu eşkıyalar, isteklerini yerine getirmelerine karşılık zengin köylüleri haydutlardan, görevini kötüye kullanan vergi memurlarından ve acımasız zaptiyelerden korurlar. Bu açıdan bakıldığında onlar itibarlı bir misyonu yüklenmiş olurlar. Fakat içlerinde çok sayıda kanun kaçaklarının ve haydutların bulunduğu çetelere hükmeden soylu eşkıyaların üstendikleri bu misyonu istikrarlı bir şekilde devam ettirdikleri söylenemez. Çünkü gerek çete üyelerinin haksız eylemleri gerekse zamanla değişen ruh hali soylu eşkıyaların halkın nazarındaki itibarını düşürür. Sürekli yakalanma ve öldürülme endişesiyle dağlarda kanun kaçağı olarak yaşayan soylu eşkıyaların sağlıklı bir ruh hali yaşamaları beklenemez. Sosyolojik şartlar zamanla soylu eşkıyaları agresif, narsis ve kaotik bir ruh haline sokar. Bu karmaşı ruh halinin sosyal alanlara yansıması baskıcı ve yıkıcı olur. Özellikle merkezi otoritenin güvenliği ve adaleti sağlayamadığı yerlerde soylu eşkıyaların halk üzerindeki baskıcı ve yıkıcı etkisi ciddi anlamda sosyal ve psikolojik travmalara sebep oluyordu.

Hobsbawm'ın tespitlerine göre soylu eşkıyalar, halkın içindedir ve ona ait bütün kültürel değerleri taşır. Giyim kuşamları ve inanç değerleriyle yaşadıkları yörenin özelliklerini taşırlar. Hükümet askerleri, bu yönleriyle onları normal köylülerden ayırt edemezler. Köylüler onları ihbar etmedikleri sürece yakalanmazlar. Ayrıca eşkyyalarla mücadele edecek kadar yeterli imkânları olmayan valiler, kaymakamlar ve paşalar, mümkün oldukça eşkıyalarla mücadele etmekten kaçınırlar. Nitekim Osmanlı Devleti'nin dağılma sürecini yaşadığı dönemlerde padişahların çıkardıkları af kanunları çetelerle mücadele edecek imkânlara sahip olmamalarından kaynaklanır. Ege'de Eşkıyalık yazarı Yetkin de bu konuda şu ifadeleri kullanır:

"Merkezi otorite çetelerle baş çıkamayınca, yenemediği güç gruplarıyla uzlaşmak isteyecektir. Uzlaşma yani af mekanizmasının işletilmesi, devletin çaresizliğinin tanımıdır. İmparatorluk tarihî boyunca devletin etkisizliğinden ötürü 'devlet-eşkıya' pazarlı̆̆ının kurumsallaştığı ve sistemleşerek resmî bir nitelik kazandığı ulaştığımız sonuçlardan biridir” (Yetkin, 1996: 95).

Soylu eşkıyaların önemli bir özelliği de mevcut yönetim sistemini ve merkezi hükümeti ortadan kaldırmak için bir isyan hareketi başlatmamalarıdır. Bu tip eşkıyalar çıkarları devam ettiği sürece feodal 
yapıyı desteklemişlerdir. Soylu eşkıyaların bir diğer özelliği vatansever olmalarıdır. Onların vatan topraklarında bağımsız bir devlet kurmak gibi bir idealleri yoktur. Devletin bekasını tehlikede gördükleri anlarda merkezi otoriteye bağlı olarak dış güçlere ve işgalcilere karşı savaşırlar. Dünya tarihinde ülkelerini işgal güçlerinden kurtarmak için bağımsızlık mücadelesi başlatan çok sayıda soylu eşkıya örnekleri bulunmaktadır. Türk tarihinde Çerkez Ethem, Demirci Mehmet Efe, İpsiz Recep, Yörük Ali ve Topal Osman bu tip efe örneklerinden sadece bir kaçıdır. Bütün bu karmaşı, çelişkili ve tutarsız yönleriyle birlikte soylu eşkıyalar devrimci olmaktan çok reformisttirler (Hobsbawm, 1999:30,31). Yetkin, Eric J. Hobsbawm’in soylu eşkıyalık konusunda yaptığı açılamalardan yararlanarak şu bilgileri verir:

\begin{abstract}
"Sosyal eşkıyalık bir tepki bir direnç kurumu olarak kır/köy insanının, denetleyemediği merkezi otoriteye ve ona bağlı olan ya da ona dayanarak yaşayan yerel otoriteye başkaldırışının simgesi yani sosyal protestonun en ilkel biçimidir. Sosyal eşkıyalık bir başka anlatımla, zenginlere, yabancı işgalcilere, baskı uygulayanlara ya da geleneksel düzeni bozup, adaletsizliği yayan sömürücü güçlere karşı, sessiz, güçsüz ve edilgen köylü kitlesinin yukarıda belirttiğimiz güçlere karşı kendini korumasının, simgesel olarak direnmesinin yaygın, somut ve evrensel bir örneğidir. Sosyal eşkıyalığı ve eşkıyalığın başkaldırısını toplumsal gelişme yasalarının doğal bir sonucu ve yaşamın gerçek bir parçası olarak ele almak zorundayız. Gerçekten bu tip eşkıyalar haksızlıkları düzeltip adaletsizliklerin öcünü almaya çalışırlar” (Yetkin, 1996:10-11).
\end{abstract}

Soylu eşkıyalar veya sosyal eşkıyalar sosyal adaleti ve düzeni sağlamak için kendilerini zengin iş adamlarının ve toprak ağalarının mallarından istedikleri gibi tasarruf etme hakkına sahip görürler. Fakir köylülerden alabilecekleri herhangi bir şey yoktur. Eşkıyaların köy zenginlerinin sağladıkları maddi imkânlarla köye yaptırdıkları köprüler, çeşmeler veya yollar fakir köylülerin desteklerini almaları açısından etkili olur. Soylu eşkıyaların fakir ve ezilmiş köylüleri korumak için yaptıkları eylemlerin doğruluğu ve tutarlılığı ise tartışma konusudur. Toprak ağalarının veya fabrika sahibi iş adamlarının mallarından zorla alarak fakir köylülere dağıtma anlayışının temelde sosyalist ve komünist ideolojiden kaynaklandığı bir gerçektir. Soylu eşkıyaların ayrıca yerel ve merkezi yöneticilere ait sosyal ve ekonomik hizmetleri baskıyla zengin köylülere yaptırmaları, emirlerine itaat etmeyen köylüleri çete mahkemelerinde yargılayıp cezalandırılmaları aslında onların vahşi eşkıyalık yönlerinin en belirgin yanıdır.

Eric J. Hobsbawm’in kullandığı soylu eşkıya kavramına karşılık araştırmada kullanılan adi eşkıyalık kavramı haydutluğu ifade etmektedir. Hırsızlık yapan, haksız yere insan öldüren, genç kızlara ve kadınlara tecavüz eden, fidye almak için dağa adam çıkaran, devlet postası soyan, ticaret kervanlarının önünü kesen kanun kaçakları halkın nazarında birer adi eşkıyadır. Hükümet zaptiyeleri köylülerin desteğini alarak bu tip eşkıyaların yakalanması için büyük mücadele verir. Adi eşkıyalar, halkın korkusu olmasa köylerde barınacak yer bulamazlar. Soylu eşkıyalardan farklı olarak kısa sürede yakalanır veya öldürülürler. Çünkü yardımseverlik ve adalet gibi onurlu yönleri olmadığı için köylülerin maddi ve manevi desteğini alamazlar.

Osmanlı İmparatorluğunun dağılma sürecinde eşkıya çetelerinin sayısı artar. Kaybedilen savaşlar, eğitimsizlik, fakir köylülerin horlanması, artan vergiler, işlenen namus cinayetleri, ekonomik kriz, sosyal adaletsizlik ve güven ortamının bozulması eşkıya sayısının artmasının en önemli sebepleridir. Ağır vergiler altında ekonomik sorunlar yaşayan, yllardan beri cephelere asker gönderen ve zabitlerin keyfi uygulamalardan bunalan köylüler, merkezi ve yerel yöneticilere karşı direnen eşkıyalara her türlü maddi ve manevi desteği verirler. Osmanlı İmparatorluğunun dağılmasından sonra yeni kurulan Türkiye Cumhuriyeti hükümeti, kısa sürede merkezi otoriteyi sağlar, halkın can ve mal güvenliği için en önemli sorunlardan birini oluşturan eşkıyaları devlet disiplini altına almayı başarır. Fakat günümüzde 
varlığını kırsal alanlarda devam ettirmeye çalışan terör örgütlerinin ve şehir merkezlerinde yapılanan mafyaların farklı türde birer çete teşkilatı olduklarını kabul etmek gerekir.

\section{5. Çakıcı Mehmet Efe}

Türk kültür tarihinde ismi hem efe hem de eşkıya sıfatlarıyla anılan Köroğlu, Pir Sultan Abdal, Dadaloğlu, İnce Mehmet, Çakıcı Mehmet, Hekimoğlu İsmail gibi birçok popüler tarihî şahsiyet bulunmaktadır. Türk edebiyatında popüler efelerin olağanüstü hayat hikâyelerini, kahramanlıklarını, yardımsever ve cesur yönlerini anlatan çok sayıda hikâye, roman, şiir, türkü ve ağıt gibi edebî eser bulunmaktadır. Adına kaleme alınan çok sayıda edebî esere, hakkında yazılan çok sayıda akademik çalışmaya ve tarihi vesikalara bakılacak olursa Çakıcı Mehmet, meşhur efelerin en başında gelmektedir. Çakıcı Mehmet Efe'nin yüksek popülaritesi reel tarihî kaynaklara da yansır. Akademisyen yazar Sabri Yetkin de tarihî vesikalardan ve sözlü araştırmalardan yararlanarak kaleme aldığı Ege'de Eşkıyalar kitabında, Çakıcı Mehmet Efe'nin Osmanlı tarihinin en büyük eşkıyalarından biri belki en birincisi olduğunu söyler (Yetkin, 1996:83). Kimilerine göre zalim ve acımasız bir eşkıya; kimilerine göre mert ve cesur bir halk kahramanı; kimilerine göre soylu bir eşkıya olan "Çakırcalı Mehmet Efe 1288 (1872) tarihinde Ödemiş̧in Birgi Bucağına bağlh Ayasüret (Türkönü) köyünde doğmuştur” (Dural, 1999:56). Çakıcı Mehmet Efe, 1883 yılında Aydın Valisi Hacı Naşit Paşa'nın öldürttüğü zeybek Çakıcı Ahmet Efe'nin oğludur. Babasının zaptiye çavuşu Boşnak Hasan tarafından öldürüldüğü tarihte Mehmet henüz on bir yaşındadır. Çocuk yaşta öksüz kalan Mehmet’i babasının en yakın dostu Hacı Mustafa yetiştirir (Yetkin, 1996:84). Çakıcı Mehmet Efe hakkında biyografik bir roman kaleme alan Yaşar Kemal, Hacı Mustafa'nın Mehmet'e babalık ettiği sürece ona:

"Sen şu değilsin. Sen Çakırcalı Ahmet Efe gibi bir adamın oğlusun. Onun yüreğinden azıcığı sana geçmişse, sen şu çalı kakıcıların topuna bedelsin. Göl yerinde su eksik olmaz. Yiğit yatağı boş kalmaz. De gayrı gün senin günündür” dediğini anlatır (Kemal, 2017:13).

Sosyal ve psikolojik şartların zorlamasıyla eşkıyalığa başlayan Çakıcı Mehmet Efe, baba dostu Hacı Mustafa'nın eski karısını ve kocasını öldürmekle ilk cinayetini işlemiş olur. Sosyal çevresinin baskısıyla bir töre cinayeti işlemiş olan Mehmet, çocuk yaşta hapse atılır. Fakat mahkeme delil yetersizliğinden küçük Mehmet’i serbest bırakır. Bu arada baba katili Boşnak Hasan, kendisinden intikam alabileceğini düşündüğü Çakıcı Mehmet’i bir hırsızlık bahanesiyle tutuklamak ister. Bu amaçla Mehmet’in ikamet ettiği köye gelir. Fakat o sırada Mehmet evde yoktur. Kin ve nefret ve korku psikolojisiyle Mehmet'in annesine hakaret eden Boşnak Hasan, sebep olacağı vahim olayların farkında değildir. "Bu cahil adamın yaptıklarl yüzünden koskoca Ege Bölgesi on beş yılı aşknn bir süre kana boyanacak ve bini aşkm insanın yaşamını tüketmesine neden olacaktı" (Yetkin, 1996:85). Çakıcı Efe, sonunda babasını katleden ve annesine ağır sözlerle hakaret eden Boşnak Hasan’ı öldürerek intikamını alır. Çakıcı Efe, işlediği bu cinayetten sonra bölgede zengin ağaların baş belası olur. Sürekli onların çiftliklerini basar, istediğini dağa kaldırır, fidye alabildiklerini serbest bırakır, alamadıklarını acımasızca cezalandırır. Çakıcı Mehmet Efe, hakkında artan şikâyetler üzerine çete üyeleriyle birlikte 25 Mayıs 1910 tarihinde Divan-ı Harp mahkemesinde yargılanır. Mahkeme yargılama sonucunda Çakıcı Mehmet Efe'nin idamına hükmeder. (Uyanık, 2014:33). Fakat Çakıcı Mehmet’ten şikâyetçi olanlar kadar ona destek veren köylüler de olmuştur. Efe'yi bir halk kahraman olarak gören köylüler Yeniköy'de onun için bir mevlit programı düzenler (Uyanık, 2014:31). Yardım ettiği fakir köylülerin ve işbirliği içinde olduğu hükümet görevlilerinin desteğiyle on beş yıl dağda kalan Çakıcı Efe bu süre içerisinde Osmanlı hükümetini çok yorar ve zorda bırakır; onun yüzünden eski Aydın vilayeti -Ege- sanki yurdun bütünlüğünden ayrılmış gibi tehlikeli duruma gelir. Osmanlı Devleti'nin dağılma sürecinden yararlanarak Ege Bölgesi'nde güçlenen Çakıcı ve çetesi uzun süre hükümetin gündeminde olmuştur. 
Hükümet güçleri Çakıcı'yı yakalayıp öldürmek ve çetesini çökertmek için çok büyük uğraşlar verir. Fakat Ege köylülerinin desteğini alan Çakıcı Efe, uzun yıllar hükümet güçlerinden saklanmayı başarır. Çakıcı çetesi ancak Çakıcı Mehmet'in ölümünden sonra çökertilebilir. Dural'ın tespitine göre Çakıcı Efe, 1327 (1911) tarihinin Ekim ayı içinde (17 Kasım 1911) Nazilli’nin Karıncalı dağında hükümet kuvvetleri ile çarpışırken meçhul bir kurşunla öldürür (Dural, 1999:56). Çakıcının ölüm haberi kısa sürede bölgede yayılır. Fakat Ege köylülerinin bir kısmı bedenine kurşun işlemediğine inandıkları Çakıcı'nın ölüm haberine inanmaz. Hükümet yetkilileri halkı Çakıcı'nın ölüm haberine inandırmak için cesedini Nazilli hükümet kapısının önünde teşhir eder. (Sun, 1934:635), (Yetkin, 1996: 173).

Ünü Osmanlı sınırlarını aşmış Çakıcı Mehmet Efe, Batılılarca Türklerin Robin Hood'u ve dağların kıralı olarak tanınır.

\begin{abstract}
"Eşkıyalık döneminde Batı kamuoyunca ilgiyle izlenmiş; onunla ilgili yazılar İtalya, İngiltere, Fransa, İsviçre ve Macaristan basınında yer almış, hatta İngiliz avam kamarasında bu ünlü eşkıya reisi ile ilgili tartışmalar yaşanmıştı" (Yetkin, 1996:83).
\end{abstract}

Yaygın inanışa göre Çakıcı Mehmet Efe acımasız bir kanun kaçağı olmakla birlikte cesur ve yardımsever bir halk kahramanıdır. Bu sebeple Sabri Yetkin, Halil Dural, Yaşar Kemal, Sabahattin Ali gibi birçok araştırmacı yazar, Çakıcı Mehmet hakkında kaleme aldıkları anlatılarında onun için hem efe ve hem eşkıya simgelerini iç içe kullanırlar. Efe'nin zalimliğinin yanında yardımsever olması, onun hem efelik hem de eşkıyalık yönünü belirgin kılar. Çakıcı Mehmet Efe'nin birbirine zıt karakter özellikleri romanların geneline aynı üslupla yansıtılır. Haydi Bre Efeler yazarı Ahmet Diker'in Çakıcı Mehmet için kullandığı şu ifadelerin toplumun efe algısını ortaya koyması açısından önemlidir.

"Efeliği boyunca astığı astık kestiği kestik bir efe olan Çakırcalı Mehmet Efe, hiçbir zaman para için dağa çıkmamıştır. Her zaman bir haksızlığa isyan ederek, düzene başkaldırmış, yöre tabiriyle çalıkakıcı yani ırz namus düşmanı olmamıştır. Zenginleri haraca bağlamış, fakirlere yardım etmiştir. Fakat fakir fukaraya el sürmemiştir" (Diker, 2016:36).

Çakıcı Mehmet Efe'nin taşıdığı bu karakteristik özellikler onu Hobsbawm’ın soylu eşkıya tipolojisine dâhil eder. Türkler için Köroğlu, İngilizler için Robin Hood, Koreliler için Honggildong, sosyal adaletsizliklere isyan etikleri için dağa çıkan, yaşamları boyunca zenginden alıp fakire dağıtan soylu eşkıya tipleridir (Lee, 20111:139-141). Lee'nin soylu eşkıya tipolojisiyle ilgili bu tespiti Türk romanları ve tiyatrosu bağlamında Çakıcı Mehmet Efe algısıyla örtüşmektedir.

\title{
1.6. Zeynel Besim Sun'un Çakıcı Mehmet Efe Romanı
}

Türk edebiyatında Çakıcı Mehmet Efe hakkında kaleme alınan ilk biyografik roman İzmir Ticaret Postası Gazetesi başyazarı Zeynel Besim Sun'a aittir. Bu romanın sonrasında Çakıcı Mehmet Efe hakkında yayınlanan diğer bazı romanlar şunlar olmuştur: Sabahattin Ali, Çakıcı’nın İlk Kurşunu (1940); Murat Sertoğlu, Çakırcalı Efe'nin Mecaraları (1947); Selami Münir Yurdatap, Çakıcı Efe (1941); Reşat İleri, Çakurcah Mehmet Efe (1952); Yaşar Kemal, Çakurcah Efe (1972); Refii Cevat Ulunay, Dağlar Krah (1995); Burhan Sabahattin, Çakurcal Mehmet Efe (2012).

İzmir Ticaret Postası Gazetesi'nde tefrika halinde yayımlanan Çakıcı Mehmet Efe romanı, gazetenin sahibi Raşit Halim B.'nin Ödemiş, Aydın, Nazilli ve Muğla köylerinde derlediği bilgilerden yararlanılarak kaleme alır (Sun, 1934:649). Romanın olay örgüsü, zamanı, mekânı ve şahıs kadrosu reel kaynaklarla örtüşmektedir. Dolayısıyla roman dönemin sosyo-kültürel özelliklerini yansıtmaktadır. Berna Moran Türk Romanına Eleştirel Bir Bakış 2 eserinde roman için: "Yarı tarihsel biyografi, yarı tarihsel roman sayılabilir" tespitinde bulunur (Moran, 2012:103). Romanın farklı bir hususiyeti de gerek reel gerekse 
kurmaca eserlerde referans kaynak olarak gösterilmesidir. Sabri Yetkin, Ege'de Eşkıyalar; Halil Dural, Bize Derler Çaktrcal 19. ve 2o. Yüzyılda Efeler; Ahmet Diker, Haydi Bre Efeler; Ahmet Cangür, Bat Anadolu'da "Efelik ve Eşkıyalı" Türküleri ve Hikâyelerinin Edebi Yönden İncelenmesi; Mehmet Öcal Özbilgin, Zeybeklik Kurumu ve Zeybek Oyunları; Türkan Gözütok, Eşkıyalık ve Çakarcalı Mehmet Efe'nin Türk Edebiyatına İzdüşümü başlıklı akademik çalışmalarında roman, tarihî bir vesika olarak kullanmışlardır. Çakırcalı'nın yarı efsaneleşmiş hayat hikâyesini Albay Rüştü Kobaş’ın verdiği bilgi ve belgelere dayandırarak romanlaştıran Yaşar Kemal, Zeynel Besim Sun'un romanının önemine şu sözleriyle dikkat çeker: "Ünlü gazetecilerden Zeynel Besim Sun, Çakırcalı hakkında uzun bir yaşantı kitabı yazmıştı. Gerçekten bu kitap Çakurcah üstüne yazılmış en ilginç kitaptır” (Kemal, 2017: 7). Halil Dural'ın Bize Derler Çakırcalı 19. ve 20. Yüzyılda Efeler eserinin önsözünü yazan Sabri Yetkin de Çakıcı Mehmet hakkında yayınlanan ilk kitabın Zeynel Besim Sun'a ait olduğunu daha sonra yazılan birçok kitabın bu kitaptan yararlanılarak kaleme alındığını belirtmektedir (Dural, 1999:XIV-XV). İzmir Ticaret Postası Gazetesi'nde 1934 yılında tefrika edilen roman, 41 formadan oluşmaktadır. Vaka örgüsüyle ilişkili fotoğrafların bulunduğu romanda, yazar-kahraman bakış açısı kullanılmıştır.

Romanda başkahraman, soylu ve vahşi eşkıya tiplemesiyle karşımıza çıkar. İç içe geçmiş, karmaşık ve birbiriyle çelişen özeliklere sahip olan Efe, inanç, namus ve irz kavramlarına büyük önem verir. Namazlarını kılmayı kurban bayramlarında kurban kesmeyi ihmal etmez. İçkinin haram olduğunu bildiği için ağzına içki sürmez. Fakirlere, yaşlıları ve hastalara merhametlidir. Çetelerin zulmüne uğrayan masum köylüleri cesaretle korur. Fakat bir de çok acımasız adaletsiz ve hain yönleri vardır. Köyden kız kaçıran kızanları diri diri ateşe atmaktan, emrini yerine getirmeyen köylüleri acımazsızca öldürmekten, onlara işkence yapmaktan hiç çekinmez. Suçlu gördüğü insanları öldürmek, cana kıymak ona âdeta bir haz verir. Gerçek olaylara ve kişilere dayandırılarak kurgulanan romanda başkahraman, bütün yönleriyle yuvarlak bir karakter olarak karşımıza çıkmaktadır. Yuvarlak karakter birden fazla farklı niteliğe sahip olabilen karakterdir ve her an okuyucuyu şaşırtır (Stevick, 2010:170). Gazeteci yazar Zeynel Besim Sun'un romanı dışındaki romanlarda Çakıcı Mehmet Efe sürekli iyilik yapan, adaletli ve cesur bir halk kahramanı olarak tanıtılır. Bu romanlarda Çakıcı Mehmet Efe düz bir karakterdir. Düz karakter, tek bir düşünceyi veya tek bir niteliği karşlayan karakter türüdür. Kurmacada görünür görünmez tanınırlar. "Okuyucu onları, aklnnı gözünden ziyade, özel bir ismi hemen fark eden duygunun gözüyle fark ederler” (Stevick, 2010:171). Düz karakterler okuyucunun belleğinde hep aynı imajda ve tutarlılıkta kalırlar. Çakıcı'nın Türk romanlarında en belirgin özellikleri cesaretli, iyiliksever ve adaletli olmasıdır. Onun bu olumlu yanları okuyucuda kendisine karşı bir hayranlık duygusu uyandırır. Çakıcı Mehmet Efe hakkında bu olumlu algı Türk sinemalarında da görülmektedir. Başrolünü Kartal Tibet'in oynadığı Çakıcı Mehmet Efe filminde (1950) Çakıcı Mehmet, zalimlere karşı korkusuzca mücadele eden, darda kalan köylülere iyilik ve yardımlarda bulunan bir halk kahramanıdır. Çakıcı Mehmet Efe'nin kahramanlık yönü tiyatro sahnelerinde de anlatılmaktadır. Devlet Opera ve Balesi Genel Müdürlüğüne bağlı tiyatro toplulukları her yıl farklı illerde Çakıcı Mehmet Efe temalı müzikli tiyatro oyunları sahnelemektedirler (Ege Dokuz Eylül Gazetesi: 6.11.2016).

\section{Metod/Yöntem}

Araştırma kapsamında olan Zeynel Besim Sun'un Çakıcı Mehmet Efe romanı, nitel içerik analizi metoduyla incelenmiştir. "Nitel içerik analizi, nitel verinin anlamını sistematik bir şekilde tasvir edilmesi için kullanılan bir metottur" (Özden ve Duru, 2016:128) Araştırmada yazllı metinlerle birlikte sözlü, yazılı ve görsel verilerden de yararlanılmıştır. Çalışmanın Giriş bölümünde araştırmanın amacı, önemi, problemi, sınırılıkları, Türkiye'de eşkıyalık tarihi, soylu eşkıyalık kavramı, Türk eşkıya tarihinde 
Çakıcı Mehmet Efe'nin kimliği ve analiz edilen Zeynel Besim Sun'un romanı hakkında bilgiler verilmiştir.

Çakıcı Mehmet Efe'nin karakter özelliklerini belirlemek için analiz edilen romanda elde edilen veriler, çalışmanın Bulgular bölümünde değerlendirilmiştir. Çakıcı Mehmet Efe'nin kurmacada tespit edilen karakteristik özellikleri çalışmanın Tartışma bölümünde reel tarihî kaynaklarla karşılaştırılmıştır. Bu bölümde soylu eşkıyalık ve adi eşkıyalık kavramları üzerinde durulmuş; Çakıcı Mehmet Efe'nin reel tarihi kaynaklara göre soylu eşkıya ve adi eşkıya vasıflarıyla örtüşen eylemleri üzerinde durulmuştur.

Doküman analiz metodunun uygulandığı çalışma sonucunda Çakıcı Mehmet Efe'nin merhametli ve yardımsever yönleriyle birlikte bugüne kadar çok da gündeme getirilmeyen yıkıcı, acımasız ve narsis yönleri ortaya çıarılmıştır.

\section{Bulgular}

Zeynel Besim Sun'un romanı dışındaki Türk romanlarında Çakıcı Mehmet Efe soylu bir eşkıya tiplemesidir. Romanların genelinde Çakıcı Efe adaletli, cesur, merhametli ve yardımsever bir halk kahramanıdır. Analiz edilen Sun'un romanında ise Çakıcı Mehmet Efe'nin soylu eşkıya özellikleriyle birlikte vahşi eşkıya özelliklerini de taşıdığı tespit edilmiştir. Çalışmanın bu bölümünde Çakıcı Mehmet Efe'nin soylu eşkıya tiplemesiyle örtüşen ve bu tiplemeye aykırı düşen eylemleri yer almaktadır.

\section{1. Çakıcı Mehmet Efe'nin Soylu Eşkıya Tipolojisiyle Örtüşen Yönleri}

Çakıcı Mehmet Efe'nin yetiştiği sosyal ortam, dağa çıma sebepleri ve on beş yıl süren eşkıyalık hayatı, karakter özelliklerini etkiler. Çakıcı Mehmet Efe, babasının hükümet zabitleri tarafından öldürülmesinden sonra devlete karşı güvenini kaybeder. Küçük yaştan itibaren baba katillerine karşı intikam duygusuyla yetişen Çakıcı Mehmet'in karakter özelliklerini belirlemede sosyal çevresinin etkisi de önemli olur. İslâmî geleneklere bağlı sosyal bir çevrede yetişen Çakıcı Efe'nin iyiliksever, merhametli ve dürüst yönleri vardır. Fakat babası hunharca katledildikten sonra devlete karşı güveni sarsılır; intikam duygusuyla mizacı sertleşir; çevresindeki insanlara şüpheyle bakar; zamanla birçok insanî değerlerini kaybeder. Baba katilini öldürdükten sonra dağa çıkan Mehmet, bölgenin en güçlü eşkıya çetesini kurar. On beş yıl kanun kaçağı olarak yaşadığı dağ şartlarında yüzlerce masum insanın ölümüne sebep olur. Çakıcı Mehmet Efe, kanun önünde suç işlemiştir. Fakat işlediği cinayet geleneksel halk kültüründe itibarlı bir eylemdir. Çünkü babasının intikamını alarak sosyal çevresinin beklentisini karşılaşmıştır. Çakıcı, her ne kadar bir çete lideri olsa da belirli ölçüde yetiştiği sosyal çevrenin örf ve âdetlerine bağlıdır. Yardımseverlik ve merhamet duygusuyla hastalara, fakirlere ve darda kalan köylülere yardım eder. Zenginden alıp fakir köylülere dağıtmanın doğruluğuna inanır. Çakıcı'nın bu yönleri onun soylu eşkıya özellikleriyle örtüşür. Bu bölümde Çakıcı Mehmet Efe'nin soylu eşkıya özellikleriyle ilişkilendirilebilecek eylemleri değerlendirilecektir.

\subsubsection{Haksızlığa Karşı Başkaldırı Yönü, İntikam Duygusu}

Soylu eşkyyalar, geleneklere göre suç olamayan, ama mevcut otoritenin suç kabul ettiği bir eylemden dolayı sistemin dışına çıkarlar. Romanda verilen bilgilere göre Çakıcı Mehmet Efe, babasının intikamını alarak dağa çıkmak zorunda kalır. Çakıcı Mehmet’in babası Ahmet Efe hükümetle anlaşarak kızanlarıyla birlikte düze iner. Fakat İzmir Valisi Naşit Paşa, zaptiye çavuşu Boşnak Hasan’a verdiği bir talimatla Çakıcı Ahmet’i öldürür (Sun, 1934:15-16). Babasının öldürüldüğü tarihte on bir yaşında olan Mehmet, katil Boşnak Hasan’a karşı büyük bir intikam duygusu taşır. Boşnak Hasan, Mehmet’in büyüdüğünde 
kendisinden intikam alacağından endişe duyduğu için onu hırsızlık bahanesiyle tutuklamak ister. Mehmet'in köydeki evine baskın yapan Boşnak Hasan, o sırada onu evde bulamaz. İstediği amaca ulaşamayan Zaptiye Çavuşu, yetim Mehmet'in annesine hakaret edip onu silahıyla taciz eder. Haksızlığa ve hakarete uğrayan köylü kadın, Yıkıklar köyü sakinlerinden Ahmet'e haber göndererek oğlu Mehmet'e yaşadıklarını anlatmasını ve ondan hem kendisinin hem de babasının intikamını almasını ister (Sun, 1934:27). Mehmet, Boşnak Hasan'ın köye gelip evlerini bastığını ve annesini taciz ettiğini haber aldıktan sonra ona karşı kin ve nefreti çok daha fazla artar. Genç Mehmet’in daha önce dağa çıkmasını gerektirecek hiç bir vukuatı yoktur. Fakat kendi iradesi dışında gelişen bu olaylar onu isyan ettirir. İlk eline geçen fırsatta baba katili Boşnak Hasan'ı ve Boşnak Hasan'ın yanında bulunan Mülazım Hüseyin'i öldürür. Roman'da Çakıcı'nın zaptiye çavuşunu niçin öldürdüğü kahraman bakış açısıyla şöyle aktarılır: "Ulan kerata elime düştün. Şimdi sana babamı kahpece öldürmeği, anamın apışına martini uzatmağı göstereceğim" (Sun, 1934:29). Anlatıcı yazar bu olayı sahneleme tekniğiyle aktardıktan sonra "İşte bu feci vakıadan sonra Çakıcı Efe'nin asıl şekavet hayatı başlamıştır” der (Sun, 1934:30-31). Efe, törelere göre namusunu temizlemiş, babasının intikamını almıştır. $O$, bu yönüyle soylu eşkıya tipolojisinin en belirgin eylemini gerçekleştirmiş olur. Zeynel Besim Sun'un Çakıcı'nın eşkıyalığa başlama sebepleri hakkında verdiği bilgiler reel tarihî kaynaklarla örtüşmektedir. Sabri Yetkin, Ege'de Eşkıyalık kitabında Çakıcı Mehmet Efe'nin babasını katleden ve annesine hakaret eden Boşnak Hasan hakkında "Bu cahil adamın yaptıkları yüzünden koskoca Ege bölgesi on beş yılı aşkın bir süre kana boyanacak ve bini aşkın insanın yaşamın tüketmesine neden olacaktı” ifadelerini kullanır (Yetkin, 1996:85). Çakıcı Mehmet Efe, namus ve intikam cinayetlerini işleyip dağa çlktıktan sonra şöhreti artar. Kurduğu çeteye dâhil olan kızanların sayısı arttıkça bölgenin en güçlü ve itibarlı efesi olur. Köylülerin Çakıcı Mehmet Efe'ye destek vermelerinin bir diğer sebebi halka kötü ve keyfi muamele yapan zaptiyeler olur. Zaten ekonomik sıkıntılar içerisinde zor günler yaşayan köylüler, zaptiyelerin zulmünden yaka silkmektedire. Bu sebeple zaptiyeler köylülerin müşterek düşmandır (Sun, 1934: 645). Ağır vergiler altında ezilen köylüler Çakııı Mehmet Efe'nin yakalanmaması için onu korur, ihtiyaçlarını karşılar. Bununla birlikte halk, Çakıcı'nın muhbirlik edenlere karşı oldukça acımasız davrandığını da bilmektedir. Köylüler, devlet yetkililerinin çözemediği sosyal ve ekonomik sorunlarını Çakıcı Efe gibi güçlü bir çete liderine sı̆̆ınarak çözmeye çalışmaktadır. Romanda bu konuda şu tespitler yer alır:

"Devlet makinesi gayet bozuk ve âcizdi. Beş kișilik bir çete ile başa çıkacak kudrete malik değildi. Bu vaziyet halkın nazarında tahakkuk edince halk kaviye taraftar oldu, âciz hükûmeti bir tarafa attı" (Sun, 1934: 644).

Soylu eşkıyanın en önemli karakteristik özelliğinden bir diğeri intikam duygusudur. Soylu eşkıyalar, haksızlık ve zulüm yapanlara karşı büyük bir intikam duygusu taşırlar. Bu kişiler paşa, vali, kaymakam gibi devlet görevlileri olsalar bile onlardan intikam almak için ellerinden geleni yaparlar.

\subsubsection{Namuskâr Yönü}

Acımasız olduğu kadar çok da merhametli olan Efe'nin en çok hassas olduğu konulardan biri de genç kızların ve köy kadınlarının namusuna verdiği önemdir. Çakıcı'nın köy bastığı, dağa adam kaçırdığı, binden fazla insanı öldürdüğü duyulur. Fakat hiçbir zaman köy kızlarına veya kadınlarına tecavüz ettiği duyulmaz. Hatta kızanlarından Veli’yi ırz düşmanlığı yaptığı için kendi eliyle öldürür (Sun, 1934:210).

Müslüman Ege köylüleri dışında Yahudi Rumlar da Çakıcı'nın namus konusundaki hassasiyetini bildikleri için onu gördüklerinde kendilerini emniyette hissederler. Romanda anlatıldı̆̆ı şekliyle Çakııı'nın Ermeni yatakları vardır. Bunlardan biri kabadayı Rumlardan Yuna'ydı. Çakııı, müfrezelerden kaçarken Yuna’nın Tire'deki değirmenine gelir. O sırada değirmene Yuna’nın dört Rum dostu da gelir. 
Genç Rumlar arasında Avrupa'dan yeni gelen İzoel Jak de bulunmaktadır. Romanda İzoel Jak ve Çakıcı arasında geçen diyalog Çakıcı'nın namuskâr, itibarlı yönünü gösterir.

“-Demek sen Avrupa'dan yeni geldin? Öyle mi?

- Evet Efe

-Benim ismimi oralarda işittin mi?

-İsmini bağışlamadın Efe. Sen kimsin?

- Ben mi? Bana Çakıcı Mehmet derler.

Çakıcı Efe mi? Çok şükür yarabbi.

Çok şükür mü? O da ne demek?

Demek şu ki Efe, çok korkuyorduk. Her adam bir olmaz. Canımız, ırzımız hepsi var. Madem sen Çakıcı Efe'sin korkumuz kalmadı" (Sun, 1934:500)

Çakıcı Mehmet Efe'yle İzoel Jak arasında geçen konuşmanın devamında Çakıcı Mehmet Efe, İzoel Jak’a “Neden ulen biz eşkıya değil miyiz?” şeklinde bir soru sorar Çakıcı Mehmet Efe'ye hayranlığıyla birlikte ondan korkusun da olan Rumlu genç bu soruya karşllı "O başka, eşkıya meselesi başka, namus meselesi başka. Biz seni işittik” şekilnde cevap verir (Sun, 1934:500).

Çakıcı Efe'nin soylu eşkıya karakterine uygun namuslu yönü romanın farklı bölümlerinde de görülmektedir. Zaptiyelerin takibinden kaçan Efe, Beşparmak dağlarında ihtiyar bir anne ve babanın misafir olur. Ev sahibi anne ve babanın Rabia adındaki genç bir kızları vardır. Talihsiz genç kız, eşkıyalar tarafından kaçırılır. Zalim Arnavut çetesine karşı kızlarının namusunu koruyamayan ihtiyar köylüler, çok endişeli ve üzüntülüdürler. Rabia'nın babası, yaşadıkları bu acı olayı daha önce hiç görmediği ve tanımadığı Çakıcı Efe'ye anlatırlar. İhtiyar köylünün anlattığına göre eşkıyalar kızlarını Çakıcı Mehmet ismini kullanarak kaçırırlar. Eşkıyaların kendi adını kullanarak genç kızı kaçırdıklarını öğrenen Efe, hemen kızanlarına emir vererek eşkıyaların yerini buldurur. Genç kızı kaçıran eşkıyalar dokuz kişilik bir Arnavut çetesidir. Soylu Eşkıyalar namuslu olmakla birlikte irz düşmanlarına karşı oldukça acımasız olurlar. Çakıcı Efe, soylu eşkıya karakterine uygun olarak genç kızı, anne ve babasına teslim ettikten sonra eşkıyaları dağda yaktırdığı bir ateşin içine atar. Çakıcı Mehmet, dostluk kurduğu bu yörük ailesiyle irtibatı kesmez, Raziye'nin düğününe gelerek boynuna yüz beşibirlik takar (Sun, 1934: 17). Çakıcı'nın daha önce tanımadığı ve aralarında akrabalık ilişkisi olamayan genç kıza ve ailesine yardım etmesi soylu eşkıya tiplemesiyle örtüşmektedir (Sun, 1934: 4-12). Raziye ve ailesi Çakıcı'nın bu iyiliğine karşı ona hayran olurlar. Romanın 22. Forma'sında da Çakıcı'nın namuskâr yönünü gösteren bir anekdot anlatılır: Çakıcı Efe soymak için geldiği bir yörük obasında da genç bir kızın Ermeni çeteleri tarafından kaçırıldığını duyar. Kızı kaçıran çetenin peşine düşen Efe aynı şekilde genç kızı kurtarır ve ailesine teslim eder (Sun,1934:340,341).

Çakıcı Mehmet Efe, dört defa evlenmiştir (Dural, 1999: 235). Düşmanlarına karşı son derece acımasız olmasına rağmen eşlerine karşı merhametli ve sevecendir. Dağda yaşadığı sürece onları ihmal etmemeye çalışır. Çakıcı'nın eşleri de Çakııı'yı sever ve ona sadakatle bağlıdırlar (Sun, 1934:155, 287). Romanda Çakıcı'nın üç defa evlendiği belirtilir. Bunların birincisi, Iraz (Raziye) Hanım, ikincisi, Kayaköylü Hacı Mehmet ağa kerimesi Fatma Hanım, üçüncüsü ise Ödemiş’in Bayezidler karyesinden Hacı Eşkıya kerimesi Nadire Hanım'dır.

\subsubsection{Yardımsever Yönü}


Toprak ağalarının sömürdüğü köylüleri korumak, muhtaçlara yardım etmek, köy halkının yararlanabileceği köprü, çeşme, cami ve yol gibi imar hizmetleri yaptırmak soylu eşkiyaların karakteristik özelliğidir. Çakıcı Efe de saklandığı ve beslendiği köylerde halkın gönlünü kazanmak için köprü, cami, çeşme ve yol gibi imar işleri yapar (Sun, 1934: 45,512).

Yetiştiği kültürel değerlere bağlı olan Çakıı Mehmet Efe, yaşlı ve fakir köy kadınlarına karşı merhametli ve yardımseverdir. Birgün köy çeşmesinden su doldurmaya gelen yaşlı bir kadını görür. Yaşlı kadının yanında ağır su testisini taşıyacak hiçbir yakını yoktur. Efe, bu köylü kadına yardım etmek ister. Silahını çekerek çeşme başındaki köylülerin korkulu bakışları arasında kadının testisine ateş eder. Testisi parçalanan yaşlı kadın, Çakıcı'ya beddua etmeye başlar. Cömert Efe, yaşlı kadına: "Nine kusura bakma bir yanlsşlık oldu. Testinin parasını vereceğim kaç kuruş istersin ?" der ve cebinden bir kese çlkararak içinden kadına 25 altın verir. Efe'nin bu cömertliği karşısında çok şaşıran köylü kadın, ona dua eder (373-374) Halkı memnun etme siyasetini çok iyi bilen Çakıcı Mehmet Efe "Kimisine kız evlendirmesi için 25 lira veriyor, kimisine de çift öküzü parası hediye ediyor, kimisine de tohumluk bedeli ihsan ediyordu" (Sun, 1934: 512).

Çakıcı'nın bir başka vasfı da fidye almak için kaçırdığı çocuklara ve zenginlere merhametli olmasıdır. İstediklerini elde edene kadar rehin aldıklarını misafir gibi ağırlar ve onlara eziyet etmez (Sun,1934:101,141,142).

Çakıcı'nın istiman zamanlarında halk, sorunlarını çözmek için hükümet memurlarından çok Çakıcı'ya müracaat ediyordu. "falan adamdan alacağım var, vermiyor"; "istediğim bir kız var, vermiyorlar" "falan tarla benim vermediler"; "falan muhtarm süresi bitti, yerine başkası geçsin" diyenler Çakıcı Mehmet'e müracaat ediyorlardı. Efe, tarafları dinleyip bir hüküm veriyor. Verdiği hüküm sorgusuz sualsiz kabul ediliyordu.

\subsubsection{Efsaneleşen Hayatı, Şöhreti ve İtibarlı Yönü}

Soylu eşkıyalar, şöhretli ve itibarlı şahsiyetledir. Bazılarının ünü ülke sınırlarının dışına da çıkmıştır. Romanda Çakıcı Mehmet Efe'nin şöhretli yönü hakkında bilgi verilmektedir. İtalyan Baron General Vanutelli ile karısının ve Tan gazetesi İzmir muhabiri M. Lustan Laufou'nun, İzmir Valisi Kâmil Paşa'dan izin alarak Çakıcı Mehmet'le Kayaköy'de görüşmeye gider. Çakıcı Mehmet’i üç metre boyunda, bir buçuk metre eninde, dört karış bıyıklı, beli palalı bir adam olarak hayal eden ziyaretçileri karşılarında orta boylu, tatlı bakışlı, nazik bir Anadolu köylüsü görünce şaşırırlar. Baron General, Çakıcı'ya bir dürbün, Madam da bir altın saat hediye etmiştir (Sun, 1934: 249, 250, 251, 252-256).

On beş yıl dağda kaldığı sürece hükümet askerleri ve zaptiyeleri tarafindan yakalanamayan ve karşısına çıkan bütün çeteleri dize getiren Çakıcı'nın ünü Avrupa ülkelerine kadar yayılmıştır. Rum dostu Yuna'nın değirmeninde karşılaştığı İzoel Jak'ın Avrupa'dan yeni geldiğini öğrenince ona Avrupa'da tanınıp tanınmadığını sorar. İzoel Jak’ın verdiği cevap Çakıcı Efe'nin şöhretini göstermesi açısında önemlidir:

\footnotetext{
"Şu bir Genç Osman meselesi var Efe. Hani sen dört bin bir muhasara hattını yarıp çıkmışsın. Sonra Genç Osman isminde birisi muhasara içinde kalmış. Muhasara hattını yarıp tekrar içeri girmişsin. Osman'ı kurtarıp yine dışarı çıkmışsın. İşte bu meseleyi Avrupa gazeteleri yazdılar ve senin için (Dağların Kralı) dediler ve o zaman okudum” (Sun, 1934: 500,501).
}

Soylu eşkıyalar, halkın itibar ettiği kişiler oldukları için siyasetçilerin ve devlet ricalinin de gözdesi olurlar. Osmanlı hükümeti Çakıcı Efe'yle düze inmesi için dört defa anlaşma yapar. İlk istimanında kendisine ve kızanlarına maaş karşılı̆̆ında kır serdarlığı verir (Sun, 1934: 69). İttihat ve Terakki 
Partisi'nin idare heyetinde olan Yakup Ağa da (Doktor Nazım), Çakıcı Mehmet’in yanına giderek onu partiye üye olması için ikna etmeye çalışır. Yakup Ağa (Doktor Nazım), Çakıcı Mehmet’i cemiyete üye yapmakla, Çakıcı'nın etkili olduğu Rumeli'de ve İzmir'de bir hareket meydana getirmeyi amaçlar. Fakat Çakıcı Mehmet Efe siyasetten anlamadığını söyleyerek cemiyete katılmayı kabul eder (Sun, 1934: 365, $366,367,368)$.

Çakıcı'nın en şöhretli yanı cesaretiydi. Beşparmak Dağları'nda kızanlarıyla birlikte korkusuzca gezebilir (Sun, 1934:539). Takibinde bulunan yüzlerce hatta binlerce müfrezeyle çatışmaktan çekinmez (Sun, 1934:342, 343, 452, 472). Gözü kara bir şaki olması, müfrezeleri bile ürkütür.

Osmanlı hükümeti baş edemediği Çakıcı Efe çetesini düze indirmek için onlarla anlaşma yolunu seçer. Hükümet, bölgenin en güçlü çetesine sahip Çakıcı Mehmet'le de dört defa anlaşma yapar. Hükümetin kır serdarı görevini Çakıcı'ya vermesi Çamlıcalı Hüseyin, Korgalı Mehmet ve Kara Hasan gibi daha önce düze inmiş çete reislerini huzursuz eder. Düze çıkan çeteler arasında bir çatışma başlaması üzerine Çakıcı Mehmet Efe, tekrar dağa çıkmak zorunda kalır.

Çakıcı Mehmet Efe, soylu eşkıya tiplemesine uygun olarak düze indiğinde halkla iç içe yaşar. Köy düğünlerine katılır, cuma namazlarını kılar, köy kahvelerinde halkla sohbet eder (Sun, 1934: 67, 69).

\subsubsection{Devlete Sadakat Yönü}

Soylu eşkıyalar, devlet sistemini ve yöneticilerini değiştirmek için mücadele etmezler. Kral, padişah, paşa, vali ve kaymakam gibi devlet erkânına suikast yapabilecek çete üyelerine sahip oldukları halde mümkün olduğunca devlet yöneticileri ve güvenlik görevlileriyle karşı karşıya gelmekten uzak dururlar. Özellikle kendilerini takip eden askerlerle silahlı bir çatışmaya girmemek için sürekli saklanırlar. Nitekim Hobsbawm’nn tespitlerine göre:

\footnotetext{
"soylu eşkıya tipolojisine göre kral (imparator, sultan, padişah) adaletin kaynağıdır ve bu yüzden 'soylu eşkıya', kralın düssmanı değil, yerel yönetici/memur veya kibar takımının ya da diğer baskıcı çevrelerin düşmanıdır” (Gözütok, 2011:61).
}

Romanda Türk insanının askerlere verdiği kutsal değere atıf yapılarak Çakıcı'nın da zora düşmedikçe askerlere kurşun sıkmadığı belirtilir. Romanda geçen ifadeyle: "Halk arasında çakıcı askere kurşun sıkmaz kanaati hükümran idi” (Sun, 1934: 645). Binden fazla insan öldüren Çakıcı'nın vali, paşa veya bir kaymakamı öldürdüğü duyulmaz. Çakıcı'nın devlete sadakatini bilen hükümet ilk düze indiğinde ona kır serdarlı̆̆ görevini verir (Sun, 1934: 69).

\subsection{6. İnanç ve Kültürel Değerlere Bağlı Yönü}

Zeynel Besim'in Çakıcı Mehmet Efe romanında başkahraman, zalim ve acımasız olmakla birlikte inançlı ve kültürel değerlere bağlı bir karakterdir. Köy baskınlarında ve çete savaşlarında bile namazını vaktinde kılmayı ihmal etmez. Romanda Çakıcı Mehmet’in günlük hayatında namazla iç içe olan hayat tarzıyla ilgili çok sayıda atıf bulunmaktadır. (Sun, 1934:56, 62, 67, 94, 95, 96, 175, 308, 378, 379, 564, 558). Romanda geçen ifadeyle "Bu adam katiyen namazın kaçırmazd. İki eli kanda olsa ne yapar ne yapar namazın kılardı” (Sun, 1934: 221). Çakıcı Mehmet'in inancından dolayı rakı içmediği bilindiği için dost meclislerinde kendisine rakı teklif edilmezdi. Suçlu gördüğü insanlara karşı son derece merhametsizdir. Fakat yaşlı, fakir ve kimsesizlere yardım ederek onların dualarını almayı önemser. Köylerde ve mahallelerde cami yapılması için çaba sarf eder (Sun, 1934:222,521) Namazın dışında oruç ibadetine de 
dikkat eder. Konakladığı köylerde sahur yapıp oruç tutar (Sun, 1934:422). Teravih namazlarını firsat buldukça kılar (Sun, 1934:312). Kurban Bayramında kurban kesmeyi ihmal etmez. (Sun, 1934:379).

\section{2. Çakıcı Mehmet Efe'nin Soylu Eşkıya Tipolojisiyle Örtüşmeyen Yönleri}

Romanda Çakıcı Mehmet Efe'nin soylu eşkıya tipolojisiyle örtüşmeyen çok sayıda eylemleri ve karakter özellikleri tespit edilmiştir. Yetiştiği kültürel değerlere bağlı olarak yardımsever ve adaletli olan Çakıcı Mehmet Efe, zamanla acımasızlaşır ve vahşileşir. Çalışmanın bu bölümünde Çakıcı Mehmet Efe'nin itibar görmeyen acımasız ve vahşi yönleri üzerinde durulacaktır.

\subsubsection{Acımasız ve Vahşi Yönü}

Soylu eşkıyaların en önemli karakteristik özelliği güvenilir ve adaletli olmalarıdır. Verdikleri sözü ne pahasına olursa olsun yerlerine getirirler. Düşman bildikleri çetelerle meydanlarda yüz yüze çarpışırlar. Anlaştıkları düşman çetelerine ihanet etmezler. Ayrıca soylu eşkıyalar, çatışma anlarında kadınlara, çocuklara ve masum köylülere zarar vermezler. Fakat romandan elde edilen bulgulara göre Çakıcı Efe'nin çok sayıda masum insanı katlettiği ve dostlarını aldattığı tespit edilmiştir. Çakıcı'nın soylu eşkıya karakterine aykırı bazı eylemleri şöyle olmuştur: Arnavut ve Çerkez çetelerinin zulmü altında ezilen Tire köylüleri içler acısı durumlarını bölgenin en güçlü çetesi olarak gördükleri Çakıcı Efe’ye anlatırlar. Çakıcı Efe, Türk düşmanı çetelere karşı güçlenmek için daha önce rakip olduğu Posluoğlu Mehmet’in çetesiyle birleşir. Posluoğlu kızanlarını ikna ederek Çakıcı Efe'nin emri altına girer. Dağlarda Arnavut ve Çerkez çetelerini arayan Çakıcı çetesi, Ali Köse ve kardeşi Cafer Kahya'yı bir baskınla öldürdükten sonra yolda karşılaştıkları beş Arnavut çobanı öldürür. Önlerinde bulunan Derepaşa Köyü ve Badem nahiyesi civarında öldürdükleri Arnavut köylüsü sayısı 27, Çerkez köylüsü sayısı üçtür. Dağ şartlarında vahşileşen Çakıcı, Türk köylülerini katleden Arnavut ve Çerkez çetelerine karşılık masum Arnavut ve Çerkez köylülerini öldürmekten çekinmez. Çakıcı Efe'nin birbiriyle çelişen bir kişiliği vardır. Kuvvetli bir din duygusuna sahiptir. Fakat çıkarları uğruna çok acımasız davranır. Dağda karşılaştığı Otuz yedi köylüyü öldürdükten sonra akşam ve yatsı namazlarını kılmayı ihmal etmez (Sun, 1934:55-56). Zeynel Besim Sun, onu bu yönüyle acımasız zalim bir musalli yani namaz kılan acımasız ve zalim bir canavara benzetmiştir. Çakıcı, yolda karşılaştığı bütün Arnavut ve Çerkez köylülerini öldürmekle kalmaz yol arkadaşı Posluoğlu Mehmet'i ve iki kızanını da gece uyurlarken kalleşçe öldürür. Zalim çete lideri, bölgenin en yakışıklı efesi Posluoğlu Mehmet’i kalleşçe öldürdükten sonra başucunda ağlar ( Sun, 1934:57).

Soylu eşkıyalar, halkın nazarında itibarlı şahsiyetlerdir. Köylüler, soylu eşkıyaların taleplerini karşılaştırdıkları sürece can ve mallarının zarar göreceğinden endişe etmezler. Romana göre Ege köylülerinin çakıcı çetesiyle karşılaştıklarında çelişkili duygular yaşadığı görülmektedir. Çakıcı istimandan sonra kızanlarıyla birlikte Yeni Pazar'a gelir. Yeni Pazar halkının ve müfrezelerin hükümetin Çakıcı çetesiyle anlaşmasından haberi yoktur. Çakıcı'nın yapacağı katliamlarından korkan halk, müfrezeleri hemen bir han odasına saklarlar. Romanda geçen ifadeyle "kimsenin beti benzi kalmamışti" (Sun, 1934:68). Çakıcı çetesi çarşıya girdiğinde köylülerin kalplerini korku ve telaş sarmıştır. Kasabada görev yapan memurlar İzmir Valiliğini arayarak durum hakkında bilgi alırlar. Alınan bilgiye göre Çakıcı çetesi hükümetle anlaştığı için düze inmiştir. Yeni Pazar halkı, Çakıcı çetesinin hükümetle anlaştığını öğrendikten sonra rahatlar. Romandaki bu sahneye göre yerleşik halkın Çakıcı Mehmet'le ilgili algıları olumsuzdur. Çakıcı Mehmet'i güvenilir bir efeden çok zalim ve acımasız bir eşkıya lideri olarak görürler. 
Ege bölgesinde kimilerine göre efe kimilerine göre eşkıya olarak görülen Çakıcı Mehmet Efe'nin çok sayıda haksız hukuksuz ve adaletsiz eylemler gerçekleştirdiği tespit edilmiştir. Bu eylemlerin bazı örnekleri şunlardır: Baba dostu Hacı Eşkıya'nın kaçan üçüncü karısını, anne ve babasını, evlendiği adamı öldürmesi (Sun, 1934: 24); İzini süren Mülazimisani Mustafa Efendi'nin ayak tabanlarını yüzmesi (Sun, 1934:40-44); Adını kullanarak kız kaçıran dokuz kişilik Arnavut çetesini yakarak öldürmesi (Sun, 1934:34); Kendi yatağı olan Fettah Bey’i kulaklarını ve gözlerini oyarak öldürmesi (Sun, 1934:167); Adagide nahiyesinden Zongur oğlunun evini basarak atını alması; takip kuvvetleri bunlarla meşgul iken Keldağ ile Subatan arasında Karaçamda Subıçkısı denilen mahalde ilk öldürdüğü Boşnak Hasan çavuşun kardeşi Ali Çavuş'u ve o sırada yanında buluna Jandarma Yörük Mehmed’i öldürmesi; Gire'de İbaklının İbrahimle karısını koyun boğazlar gibi kesmesi; Kışla köyünde Kamalı Mustafa'nın annesini öldürmesi; Ayasurat köyünde de Kara Haliloğlu Ali ile teyzesini öldürmesi (Sun, 1934:197-198). Adi eşkıyalar, intikam duygusuyla hareket ettikleri anlarda oldukça zalim ve adaletsiz olabilirler. İntikam duygusuyla zalimlerin yanında masumlara da zarar verir; onları da öldürebilirler. Çakıcı Efe bu yönleriyle adi eşkıya tipolojisine uymaktadır.

Romanda Çakıcı Mehmet Efe'nin çok sayıda masum Çerkez ve Arnavut köylüsünü acımasızca öldürdüğü anlatılmaktadır. Çakıcı Efe'ye göre bir adamı öldürmek için Arnavut olması yeterlidir (Sun, 1934:348, 502, 508, 557, 558).

Çakıcı Mehmet Efe, o kadar vahşi ve acımaszıdır ki hükümet askerleri ve zabitleri onunla karşı karşıya gelmekten korkar (Sun, 1934:372). Romanda anlatıldığı şekliyle çete lideri, sekiz askere pusu kurar ve pusuya düşürdüğü askerleri acımasızca öldürür. Çakıcı Mehmet, öldürdüğü askerlerin kafalarını kesecek kadar da vahşileşir. Sun'un ifadesine göre Çakıcı Mehmet Efe bu olaydan sonra canavarlaşır, vahşi ve hunhar olur (Sun, 1934:377). Bu vahim olaydan birkaç gün sonra Çakıcı, Çerkez Ali'ye pusu kurup Çerkez Ali'nin dilini keser (Sun, 1934:390). Zalim eşkıya bununla da kalmaz Kamalı Zeybek'in annesini öldürür (Sun, 1934: 393). Çakıcı'nın göz ardı edilen farklı bir yönü de haydutluğudur. Romanda anlatıldığına göre Çakıcı Mehmet kızanlarıyla birlikte Muğla posta arabasının önünü keserek içindeki paraları gasp eder (Sun, 1934:397-398). Çakıcı'nın masum çocukları da katlettiği vuku bulur: Birgün Mutaf'ın evini basar ve ateşe verir. Orada olan biri 13 diğeri de 15 yaşlarında iki Yahudi çocuk heyecan ve telaşla "yangın var" diye bağırmaya başlarlar. Merhamet duygusunu yitiren Çakıcı, iki el ateş ederek iki çocuğu boş birer çuval gibi yere serer (Sun, 1934:414). Dağ şartlarında vahşileşen Çakıcı Efe, zengin köylüleri ve çocuklarını dağa kaçırıp karşılığında fidye almaya başlar. Mehmet Mutaf’n oğlunu fidye istemek için kaçırırken yolda Dedeoğlu ve oğlunu görür, onları da yanına alır. Dedeoğlunun oğlu, bir köşe başından fırlayıp kaçmak isterken bir kurşun ile çocuğu öldürür. Çakıcı Mehmet için adam öldürmek, parmak çıtlatmak kadar kolay bir şeydir (Sun, 1934:419). Bayındırlı Mehmet Efendi’nin müfrezelerinden kaçarken yolda yetmişlik bir ihtiyarla 12 yaşındaki bir çocukla karşılaşır. İhtiyar kadının ve çocuğun kendisini ihbar etmelerinden endişelenir. Bu endişeyle de iki masum köylüyü öldürür (Sun, 1934:471). Çakıcı Mehmet Efe, kanun kaçağı olarak yaşadığı tabiat şartlarında zamanla çok acımasızlaşır yıkıcı bir ruh haline bürünür.

\subsubsection{Trajik Sonla Biten Yönü}

Ege köylerinde bir halk kahramanı olarak görülen Çakıcı Mehmet Efe'nin ölümü soylu eşkıya tipolojisiyle örtüşmemektedir. Efe'nin ölümünden sonra yaşanan hadisler trajiktir. Tarihçi Hobsbawn halkın onurlu ve sevilen sosyal eşkıyaların ölümüne inanmak istemediğini onun kurşun işlemez, olağan üstü güçlere sahip olduğuna inandığını söylemektedir (Yetkin,1996:173). Romanda anlatıldığına göre Çakıcı Mehmet Efe'nin ölüm haberine de halk inanmamıştır. Gerçekte Çakıcı, hükümet zaptiyelerinden 
kaçarken yanlışlıkla bir kızanı tarafından vurularak öldürülmüştür. Fakat halkın kimi korkusundan kimi ise sevgisinden bu habere inanmamıştır. Hükümet yetkilileri Çakıcı Mehmet Efe'nin ölüm haberini ilan ettikten sonra halkı bu habere inandırmak için Efe'nin cesedini, Nazilli hükümet konağın kapısına asar (Sun, 1934:635), (Yetkin, 1996: 173). Daha sonra Çakıcı Mehmet Efe'nin cesedi Nazilli mezarlı̆̆ına gömülmek istenmiştir. Fakat Nazilli halkının itirazı üzerine Çakıcı Mehmet Efe'nin cesedi Nazilli, Ödemiş, Alaşehir yolu üzerinde bir çukura gömülmüştür. Soylu eşkıyalar halkın nazarında kutsal sayılır ve halk onlara milli bir kahraman gibi değer verir. Çakıcı Mehmet Efe'nin trajik sonu soylu eşkıya tipolojisiyle örtüşmemektedir.

\section{Tartışma}

Çakıı Mehmet Efe, romana yansıyan yönleriyle yardımsever, merhametli cesur ve mert olduğu kadar acımasız, narsis ve yıkıcı bir karakterdir. Çalışmamızın bu bölümünde Çakıcı Mehmet Efe'nin kurmacada tespit edilen karakteristik özellikleri reel tarihî kaynaklarla karşlaştırılacaktır. Yapılacak karşılaştırmada Çakıcı Efe'nin soylu ve adi eşkıya tiplemesine uyan ve aykıı düşen yönleri tartışılacaktır. Bu konuda özellikle Halil Dural'ın Bize Derler Çakurca 19. ve 20. Yüzyılda Ege'de Efeler, Sabri Yetkin'in Ege'de Eşkıyalar kitaplarından ayrıca Ercan Uyanık'ın Çakırcah Mehmet Efe'nin Kronolojisi Ege Defteri başlıklı makalesinden yararlanılacaktır.

\subsection{Reel kaynaklarda Çakıcı Mehmet Efe}

Halil Dural'ın Bize Derler Çakırca 19. ve 20. Yüzyılda Ege'de Efeler kitabının orijinal adı Ödemiş Tarihinde Zeybek olup kitabın 83-91 sayfa aralı̆̆ında Çakıcı Mehmet Efe hakkında bilgiler bulunmaktadır. Halil Dural, 1884 yllında Ödemiş’te dünyaya gelmiş ve 1904 yllından 1937 yılına kadar memleketinde öğretmenlik yapmıştır (Dural, 1999:VI-VII) Ödemiş tarihi hakkında araştırmaları olan öğretmen Halil Dural'ın özel olarak ilgilendiği konulardan biri de on dört yaşında karşılaştığı Çakıcı Efe Mehmet olmuştur. Halil Dural emekli olduktan sonra (1937) döneme tanıklık eden altmış civarında Ege köylüsüyle görüşmeler yapmış, Çakıcı Mehmet’in gizemli hayatını aydınlatacak çok önemli bilgi ve belgelere ulaşmıştır. Halil Dural, çalışmalarında uyguladı̆̆ı metot hakkında şu ilgileri verir:

a. "Kendi müşahedelerim

b. Hadiselerin içinde yaşayanları ifadelerini yine kendi ağızlarından dinlemek suretiyle

c. Çakırca hakkında yazılan bugüne kadar bütün eserlerin iddia ve mütalaalarını akıl ve mantık süzgecinden geçirdikten sonra bunlardan da faydalanmak suretiyle" (Dural, 1999:XV).

Zeynel Besim Sun'un romanıyla karşıllaştırdığımız Bize Derler Çakırca 19. ve 20. Yüzyılda Ege’de Efeler kitabı, dönemin tanıklarından veya tanıkların yakınlarından yararlanılarak hazırlanmıştır. Dolayısıyla Çakıcı Mehmet Efe hakkında nitelikli ve reel bilgiler içermektedir. Yazarın sözlü tarih araştırma metodunu kullanarak derlediği bilgiler Sabri Yetkin tarafından yayına hazır hale getirilmiştir. Ege Bölgesi'nin soyo-kültürel tarihi üzerine araştırmaları olan Sabri Yetkin'in Ege'de Eşkıyalık kitabı ise yazarın doktora tezine dayanmaktadır. "Kitapta Eşkıyahğın Osmanh İmparatorluğu’nda özellikle Ege Bölgesinde ortaya çıkış nedenleri, kronikleşmesi ve bu sorunun çözümlenememesi üzerinde durulmuştur" (Dural, 1999:VI). Yeni tarihçilik yani mikro tarih anlayışıyla hazırlanan çalışmada orijinal, dokümanter malzeme kullanılmıştır. Osmanlı arşivlerinden yararlanılarak aktarılan olaylar döneme tanıklık eden kişilerin tanıklıklarıyla desteklenmiştir. Kitapta Çakıcı Mehmet’in soylu ve adi eşkıya tipolojisiyle örtüşen çok sayıda eylem gerçekleştirdiği tespit edilmiştir. Yetkin, Çakıcı Mehmet’in eşkıyalık eylemlerini anlattığı bölümlerde Zeynel Besim Sun'un romanını referans kaynak olarak kullanmıştır (Sun, 1934:92,113,115,117). Halil Dural Efe'nin Fukaraseverliği başlıklı bölümünde Çakıcı 
Mehmet'in yardımsever ve mert yönünü anlatır. Kitapta yer alan bilgiye göre Efe, Genev (Zeytinlik) köyünde aç sefil yaşayan Kişkiş Mehmet'le tanışır. Kişkiş’in perişan halini gören Efe, ona cebinden çıkardığı on Osmanlı altınını vererek altınları ailesi için harcamasını söyler (Dural, 1999:149-150).

Sabri Yetkin'in Ege'de Eşkıyalar başlıklı çalışmasına göre Çakıcı'nın dağa çıkma sebebi Boşnak Hasan olmuştur. Boşnak Hasan, Çakıcı Mehmet’in babasını pusuya düşürerek öldürür; intikam alacağından endişe ettiği oğlu Çakıcı Mehmet’i tutuklamak ister. Köy baskınında Çakıcı Mehmet’in annesini taciz eden Boşnak Hasan, Ege Bölgesinde on beş yll sürecek asayişsizliğe ve katliamlara sebep olur. Yetkin, Ege'de Eşkıyalık eserinde Boşnak Hasan'ı kastederek, “Bu cahil adamın yaptıkları yüzünden koskoca Ege Bölgesi on beş yılı aşkın bir süre kana boyanacak ve bini aşkın insanın yaşamını tüketmesine neden olacaktı" (Yetkin, 1996:85). ifadelerini kullanır. Çakıcı'nın dağa çıma sebepleri kurmacada ve reel kaynaklarda verilen bilgilerle örtüşmektedir. Çocuk yaştan itibaren Boşnak Hasan'a karşı intikam duygusuyla yetişen Mehmet, nihayetinde izini takip ettiği Boşnak Hasan’ı̈ öldürür. Törelere göre asil bir eylem işleyen Mehmet, kanun önünde suçlu duruma düşer. Yargılanmamak için dağa çıkar, on beş yıl çete faaliyetleri yapar. Ege'de Eşkıyalar kitabında Çakııı Mehmet'in soylu ve adi eşkıya tipolojisiyle örtüşen eylemleri şu şekilde tespit edilmiştir:

\title{
Soylu eşkıyalık yönüyle ilgili tespitler:
}

\begin{abstract}
“Özellikle başkonsolos Paul Blanc, Cakırcalı Efe’nin adi bir esskıya olmadığını, yaptıklarının Alexsandre Dumas'ın Üç Silahşörler'inin serüvenlerinin şüphesiz gölgede bıraktığını, yoksul köylüye yardım ettiğini, köprü ve yol yaptığını söylüyordu” (Yetkin, 1996:83); “Ancak bu süreçte fakir halkın sevgilisi, kahramanı, babası gibi görülmüss ve bir anlamda yılgın, ezilmiş, edilgin köylünün hak arayıcısı ve sözcüsü olmuştu; bu yüzden köylüden her türlü desteği görmüştü” (Yetkin, 1996:83); "Çete ise bu arada Ödemiş-Aydın civarındaki dă̆ köylerini dolaşıp, fakir insanlara yardım ediyor, evlenemeyen genç kızlara çeyizlik, erkeklere başlık ve düğün parası vererek, mültezim, ağa soygunundan bıkmış, devletin eziyetinden, zulmünden yılmış insanları kendi saflarına çekmeye çalışıyordu. Bu konuda başarılı da olmuştu" (Yetkin, 1996:88); "Başı sıkışan, arazisini zengine kaptıran, mültezimin zulmüne uğrayan, soluğu efenin yanında alıyordu. Çakırcalı da efe olmanın sorumluluğunu taşıarak, haksızlıkları gidermek için çaba gösteriyor, adalet dağıtan mahkeme gibi hareket ediyordu" (Yetkin, 1996:99); "Meşrutiyet hükümetinin çalışmaları ve Men-i Şekavet Kanunu'nun zorlamalarıyla, halk asayiş konusunda yönetime yardımcı olmaya başlamışken bile Çakırcalı çetesi halka olan yakınlığını sürdürmekteydi” (Yetkin, 1996:142).
\end{abstract}

Adi eşkıyalık yönüyle ilgili tespitler:

“Çakırcalı, eşkıyalık serüveni boyunca bir ölüm makinesi gibi çalışmıştı” (Yetkin, 1996:86);“Parası tükenen çete, bir olay daha gerçekleştirdi, Ödemiş civarında Kız oğlu Mehmet ağayı dağa kaldırıp yüklü bir fidye daha aldı" (Yetkin, 1996:88);

Çakıcı Mehmet Efe çetesi bölgedeki zengin köylülerin başına tam bir bela olur, sürekli toprak ağalarının çiftliklerini basar, fidye almak için dağa adam kaldırır. (Yetkin, 1996:91). Çakıcı Efe'nin emirlerini yerine getirmeyen köylüler, çete mahkemelerinde yargılanarak en ağır şekilde cezalandırılır. Yetkin'in Ege'de Eşkıyalar başlıklı kitabında Çakıcı’nın adi eşkıyalık yönünü gösteren farklı eylemleri şunlar olmuştur:

“Çakırcalı, arkadaşlarını kurtarırken; iki müfrezenin tamamını öldürmüş ve sağ bıraktığı müfreze kumandanı Mülazım Mustafa Efendi’nin taban derilerini yüzmüștü” (Yetkin,1996:91); "Çakırcalı pazarlığı tamamlanmadığı için affa uymadı, eşkıyalığını iyice artırarak büyük bir baskın düzenleyip yirmi kişiyi öldürdü” (Yetkin, 1996:96); “Durum öylesine 'vahim' bir hale gelmişti ki, kaza merkezlerinde oturan zengin ağalar ve ileri gelenler Çakırcalı korkusundan İzmir'e göç etmeye başladılar" (Yetkin, 1996:96); "Kır serdarı Çakırcalı Mehmet, resmî görevli olmasına ve devletten maaş almasına rağmen, yönetimin emirlerini dinlemiyor, başına buyruk çalışıyor ve nerede bulunduğunu kimse bilemiyordu... Çamlıca çetesine bir şey yapamamanın acısını halktan çıkarıyor, resmî haydut gibi davranarak soruşturma yapıyorum diye adam dövüyor ya da öldürüyor, halkın şikâyetçi olmaması için de onları tehdit etmekten geri kalmıyordu” (Yetkin, 1996:99-100); "Bu arada 
Çakırcalı, Aydın sancağına geçerek, üç sene önce kendisine oyun oynayan ve yörenin en zengin kişisi olan Barutçu İstavri Efendi’nin fabrikasını basıp, bin lirasını aldı" (Yetkin, 1996:99-107); "Kamil Paşa, bu döneme ilişkin hazırladığı raporlarda Çakırcalı'nın korkunç derecede zalimleşip üç ayda altmıș kișiyi öldürdüğünü belirttikten sonra, çetenin köylüleri kendilerini ihbar etmemeleri için tehdit ettiğini, ihbar edenleri öldürdüğü için, yöreden muhbir ve kılavuz temin edilemediğini söyler" (Yetkin, 1996:99-114);

Kitapta Çakıcı Efe'nin sanılanın aksine asker öldürdüğüne ait bilgiler de bulunmaktadır. 11 Eylül 1909 tarihinde Çakıcı çetesi, Manisa Jandarma Alayı binbaşılarından Rüstem Bey’i ve on iki askerini pusuya düşürür. Çıkan çatışmada Binbaşı Rüstem Bey ve sekiz asker öldürülmüştür. (Yetkin, 1996:99-100). Çakıcı Efe'nin eylemlerine devam ettiği dönemde Ege Bölgesi’nin en yoğun iş zamanıdır. Bölgenin en önemli zenginlik kaynağı olan incirler kurutulmakta, bağbozumu yapılmaktadır. Bahçelerinde son sürat çalışan halk, eşkıyanın son eylemlerinden sonra korkusundan bahçelerini terk etmek zorunda kalır. Köylülerin bahçelerindeki ürünlerini toplayamamaları bölge ekonomisine büyük zarar verir" (Yetkin, 1996:99-130).

Çakıcı Mehmet Efe'nin adi eşkıyalık yönünü gösteren eylemler farklı kaynaklarda da geçmektedir. Ercan Uyanık'ın Çakırcalı Mehmet Efe'nin Kronolojisi başlıklı çalışması bu kaynaklardan biridir. Uyanık, Zeynel Besim Sun'un romanı dahil olmak üzere farklı kaynaklardan yararlanılarak kaleme aldığı Çakırcalı Mehmet Efe'nin Kronolojisi başlıklı yayınında Çakırcalı Mehmet’in adi eşkıyalık yönünü gösteren çok sayıda kanunsuz eylemini tespit etmiştir. Osmanlı arşivlerinin resmî kayıtlarına dayandırllarak belirtilen bu eylemlerden bazıları şunlardır:

\begin{abstract}
"Çakırcalı dağa kaldırdığı kişileri fidye karşılığı serbest bıraktı” (Uyanık, 2014:10); "Çakırcalı Tire kazasının zenginlerini tehdit edip yüklü miktarda para istedi” (Uyanık, 2014:11); "Çakırcalı kır serdarı görevinde eşkıya takibindeyken Alaşehir Burhan beldesi muhtarını öldürüp bir kadını dövdü ve olayı hükümete haber vermemeleri için ahaliyi tehdit etti” (Uyanık, 2014:15); “Çakırcalı Mehmet, Salihliye bağlı Manastır Köyü’nde bir çocuğu öldürüp bir kadını dövdü ve olayı hükümete haber vermemeleri için ahaliyi tehdit etti” (Uyanık, 2014:16); "Çakırcalı Milas'ın zengin ailelerinden Manolaki Hacı Pordumorus'un iki oğlunu dağa kaldırarak dört bin lira fidye istedi” (Uyanık, 2014:18) "Çakırcalı Aydın demiryolu üzerinde bir fabrikayı yaktı” (Uyanık, 2014:29); Çakıcı Mehmet Efe ve çetesinin idama mahkum olduğunu bildiren Divan-ı harp mazbatası vilayete gönderildi.(Uyanık, 2014:33); Çakıcı Mehmet Efe, takibine gelen iki jandarmayı öldürüp, birini yaraladı (Uyanık, 2014:40).
\end{abstract}

Araştırma kapsamındaki reel kaynaklara göre Çakıcı Mehmet Efe'nin içlerinde asker, çocuk ve kadınlarında bulunduğu birçok insanı katlettiği, posta soyduğu, Ege köylülerine türlü şekillerde eziyet ettiği tespit edilebilmektedir. Çakıcı Mehmet Efe'nin soylu eşkıya tipolojisine aykırı bu tip eylemler reel kaynaklar arasında tutarlılık göstermektedir.

\title{
4.2. Kurmaca kaynaklarda (Romanlarda) Çakıcı Mehmet Efe
}

Türk edebiyatında Çakıcı Mehmet’in tarihî kişiliğini romanlaştıran yazarlar arasında başta Sabahattin Ali ve Yaşar Kemal olmak üzere Selami Münir Yurdatap'nn, Reşat İleri’nin, Refii Cevat Ulunayve'nin, Murat Sertoğlu'nun ve son olarak Burhan Sabahattin’in Çakıcı Mehmet algısı olumludur. Özellikle Çakıcı Mehmet'in dağa çıkış sebeplerini sosyolojik açıdan değerlendiren Sabahattin Ali ve Yaşar Kemal, romanlarında Çakıcı Mehmet Efe'yi Abdülhamit yönetimindeki mevcut düzene karşı isyanın ve direnişin sembolü olarak görürler. Gözütok’un tespitine göre:

“Sabahattin Ali, Çakıcı'yı idealize bir tip olarak sunmuş, Çakııı'yı kendi ideolojisine göre yeniden yorumlamış ve Çakıcı'yı doğuran toplumsal şartları, II. Abdülhamid döneminin görece bozuk düzenine bağlamıştır" (Gözütok, 2011:57). 
Sosyal adaletsizliğe ve eşitsizliğe başkaldıran popüler tipleri İnce Mehmet örneğinde olduğu gibi romanlaştıran Yaşar Kemal, Çakırcalı Efe romanın önsözünde romanın ana kaynakları ve yazılma serüveni hakkında bilgi verir. Yaşar Kemal, bu tarihî romanını Çakıcı çetesinin izini süren Albay Rüştü Kobaş'ın verdiği bilgi ve belgelere dayandırarak kaleme almıştır. Kurmaca eserde Çakıcı Mehmet, soylu eşkıya tipolojisine uygun olarak cesur, mert ve yardımseverdir. Fakat Çakıcı Mehmet'in adi eşkıya tipolojisine dâhil edilebilecek hain, adaletsiz ve acımasız yönleri de vardır (Gözütok, 2011:66). Yaşar Kemal'in tespitine göre Çakıcı binden fazla insanı öldürmüş on beş sene dağların asayişsiz kalmasına sebep olmuştur (Kemal, 2017:8). Fakat Marksist ve sosyalist yazar, aynı ideolojik görüşü paylaştı̆̆ Sabahattin Ali gibi Çakıcı'nın yasa dışı eylemlerini meşru sebeplere dayandırır. Romanda yazar bakış açısıyla geçen ifadeler şöyledir:

\begin{abstract}
"Hâlbuki Çakırcalı eşkıyalığı, adam öldürmeyi sevmiyordu. Adam öldürmek, soymak, eşkıyalık yapmak zorunda bırakılmıştı. Demek ki öldürdüğü soyduğu insanlardan sorumlu değildi. Kendisini eşkıyalığa zorlayan kuvvetti. Bu neydi? Padişah mı, millet miydi? Suç onların. Birinden birine yükleyemiyordu suçu ama bildiği şey, kendisi hiç mi hiç suçlu değildi. Yüreği temizdi. Yedi yaşında bir çocuğun yüreği gibi. Kime kıymıştı şimdiye kadar? Hasan Çavuş’a, kendi adını kullanarak halka zulmedenlere, Padişahın adamı olan Çerkezlere, Arnavutlara, yedi mecidiye için zaptiye yazılıp, kendisini öldürmek için arkasına düşenlere kıymıştı. Haksız mıydı?” (Kemal, 2017: 110). Romanda Çakıcı Mehmet Efe, hem iyi hem de kötü yönleri olan yuvarlak bir karakterdir. Yazar-bakış açısıyla: "Çakırcalı zengin soyuyordu. Fabrika yakıyordu. Önüne geleni öldürüyordu. Artık hükümet ortadan silinmiş gibiydi. Dövüşü, kavgası olan, zulüm gören, yoksulluğa düşen, kız kaçıran, hükümete değil, Çakırcalıya geliyordu. Çakırcalı bir mahkeme, Çakırcalı bir maliye, Çakırcalı doktor, Çakırcalı ilaçtı" (Kemal, 2017:110).
\end{abstract}

Yaşar Kemal, romanında “Çakırcalı'yı İngiliz tarihçi E. J. Hobsbwm’ın 'soylu eşkıya' tipolojisine göre yorumlayarak romantik ekolün izinden gider. Fakat Çakırcalı olayının çok yönlü ve çok karmaşık bir olay olduğunun altını çizer" (Gözütok, 2011: 49). Romanda Çakırcalı Mehmet Efe'nin bazı olumsuz eylemleri anlatılsa da okuyucunun Çakırcalı Mehmet Efe hakkındaki genel algısı olumludur.

Sabahattin Ali ve Yaşar Kemal, Çakırcalı Mehmet Efe'yi ağırlıklı olarak efsaneleşen soylu tavırlarıyla tanıtmaya çalışırken Zeynel Besim Sun, onu çok yönlü ve birbirine zıt farklı karakter özellikleriyle tanıtır. Sun, döneme tanıklık eden kişilerden edindiği bilgi ve belgelere göre Çakıcı Mehmet Efe'yi zalim ve acımasız adi bir eşkıya tiplemesiyle anlatır. Gazeteci yazar, aksiyoner olayların anlatıldığı romanının sonunda Çakıcı Mehmet hakkında şu ifadeleri kullanır:

\begin{abstract}
"Çakıcı Efe, şimdi Cumhuriyet devrinde sağ olsaydı acaba dağlarda kaç gün dolaşabilirdi? Hükümet kudretinin bu satveti zamanında dağlarda eşkıya yaşamasının imkânı var mıdır? Eşkıya yaşayamaz. Çünkü şekavettin ilk şartı halka yaslanmaktır. Bugün hangi köylü, hükümeti bırakıp da bir şakiye muzahir olur. Hükümetle halk dün başka başka şeylerdi. Hâlbuki bugün halk demek hükümet denektir, hükümet makinası bizzat halkın elindedir. Halk, kendi aleyhine kıyam eden bir şakiye nasıl muzaheret eder" (Sun, 1934:645).
\end{abstract}

Sun'un aktarımlarına göre Çakıcı Mehmet, fakir köylülere yardım etmiş, açları doyurmuş, yol, çeşme, cami ve köprü yaptırmıştır. Fakat Çakıcı’nın bu cömertliği ve yardımseverliği stratejik bir amaç taşır. Romanda geçen ifadeye göre: "Çakıcı köprü yaptırır, yol düzeltir, derler. Evet bunlar doğrudur, ama babasinin hayrna yaptormazd, icabinda kendi kullansin diye yaptırtrdı" (Sun, 1934:550). Köylüler, Çakıcı'nın bu köprüleri kendileri için yaptırdığını düşünürler ve bu sebeple onu müfrezelerden korurlardı.

Çakıcı, emirlerini yerine getirmeyen köylülere karşı acımasızdır. Çakıcı Mehmet Efe'nin faaliyet alanı içerisinde stratejik önemi bulunan Büyük Menderes ve Küçük Menderes üzerinde köprü yoktur. Çakıcı Mehmet, köprü yapma görevini köyün zenginleri arasında bulunan Osman Bey’e verir. Fakat Osman 
Bey yanındaki Çerkezlere güvenerek Çakıcı'nın bu emrini yerine getirmez. Çakıcı Mehmet, kızanlarıyla birlikte Osman Bey'in köyünü basarak onu öldürür. Dinî yanı güçlü olan Çakıcı Mehmet Efe, Cuma namazını kıldıktan sonra Mehmet Ağa’nın oğlunu yanlarına alarak tekrar dağa çıkar (Uyanık, 2014:42).

Zeynel Besim Sun, cesur olduğu kadar zeki ve sinsi olan Çakıcı Efe hakkında şu yorumlarda bulunur:

“Çakıcı Efe, şeytan gibi zekâsıyla köylüyü tutmasını bilmişti. O alın teriyle kazanmış gibi elindeki paradan köylüye bir kısım vermesini, kızı gelin etmesini, hastalara ilaç parası yollamasını bilirdi. Bu sebeple zamanın köylüye insan muamelesi etmeyen hükümetine pek ısındık olmayan köylü eşkıyaya müzaheret ediyordu" (Sun, 1934:45).

Sabri Yetkin de Çakıcı Efe'nin çetesini güçlendirmek ve hükümet zaptiyelerine yakalanmamak için köylülere iyilik ettiği tespitinde bulunur. Yetkin, Ege'de Eşkıyalar kitabının Çakırcah Mehmet bölümünde şu ifadeleri kullanır:

“Çete ise bu arada Ödemiş-Aydın civarındaki dağ köylerini dolaşıp, fakir insanlara yardım ediyor, evlenmeyen genç kızlara çeyizlik, erkeklere başlık ve dügü̈n parası vererek mültezim ağa soygunundan bıkmış, devletin eziyetinden zulmünden yılmış insanları kendi safına çekmeye çalışıyordu” (Yetkin, 1996: 88).

Araştırma kapsamında olan kaynaklarda Çakıcı Mehmet Efe'nin devlete sadakati ve asker sevgisi konusunda çelişkili bilgiler yer almaktadır. Sun, romanında Çakıcı Efe'nin on beş yıl dağda kalma ve binden fazla insanı öldürme sebepleri anlatılırken yeni ideoloji lehinde şöyle der:

“Türk milleti askerdir ve bu sebeple askeri çok sever. Siz şu satırları okurken kapınızın önünden bir bölük asker geçse derhal gözünüzün yaşardığını hissedersiniz. Çakıcı Efe, halktaki bu ruhî haletin farkında idi. Bu sebeple daima askerden kaçtı ve askerle müsademe kabulünden içtinap etti. Halk arasında (Çakıcı askere kurşun atmaz) kanaati hükümran idi” (Sun, 1934:645)

Fakat romanın farklı bir bölümünde Çakıcı'nın pusuya düşürdüğü sekiz Türk askerini acımasızca öldürdüğü ve başlarını kestiği belirtilmektedir (Sun, 1934:377). Çakıcı’nın asker öldürdüğüne dair bilgiler reel kaynaklarda da geçmektedir (Yetkin, 1996:99-100). Ayrıca romanda Çakıcı Mehmet Efe'nin haydutluk yaptığına dair bilgiler de bulunmaktadır. Çakıcı Mehmet, Muğla posta arabasının önünü kesip hazineye ait paraları gasp etmiştir (Sun, 1934: 397-398). Çakıcı Mehmet Efe'nin Muğla postasına yönelik bu eylemi Halil Dural'ın araştırmalarında da yer almaktadır. Halil Dural, Çakıcı'nın bu eylemi hükümetten intikam almak için gerçekleştirdiğini söyler (Dural, 1999:280). Halil Dural'ın dışında Ercan Uyanık da Osmanlı arşivlerinde bulunan resmi bilgi ve belgelere dayanarak Çakıcı Mehmet'in posta soyduğunu tespit eder (Uyanık, 2014:18,34).

Halk, her ne kadar varlığından büyük endişe duysa da soylu eşkıyaların ölüm haberi karşısında üzülür. Çok değer verdikleri bir halk kahramanı veya bir kanaat önderi gibi soylu eşkıyaların cesedine sahip çıkarlar. Soylu eşkıyaların mezarları da önemsenir. Fakat Çakıcı Mehmet Efe'nin ölümü ve sonrası yaşanan trajik olaylar soylu eşkıya tipolojisiyle uyuşmamaktadır. Sun'un anlatımına göre Çakıcı Mehmet Efe, zaptiyelerden kaçarken kaza kurşunuyla öldürülmüştür. Yetkin de Ege Eşkıyalar adlı kitabında Çakırca'nın bir kaza kurşunuyla öldürüldüğünü tespit etmiştir (Yetkin, 1996: 172) Halk arasındaki yaygın inanışa göre Çakıcı'ya kurşun işlemezdi, olağanüstü cesareti ve gücü olan Çakıcı'nın öldürüldüğüne kimse inanmıyordu. Hükümet yetkilileri hem halkı ikna etmek hem de kanun kaçağı eşkıyalara ibret olsun diye Çakıcı'nın cesedini Nazilli hükümet konağının bahçe kapısına asılarak teşhir etmişlerdir (Sun, 1934:635), (Yetkin, 1996: 173). Çakıcı'nın cesedi Nazilli mezarlığına gömülmek istenmiştir. Fakat Nazilli halkı, bir eşkıya cesedinin kendi mezarlıklarına gömülmesini kabul etmedikleri için ceset Nazilli, Ödemiş, Alaşehir yolu üzerinde bir çukura gömülmüştür (Sun, 1934:635). 


\section{Sonuç}

Zeynel Besim Sun'un Çakıcı Mehmet Efe romanı 1934 yılında İzmir Ticaret Postası Gazetesi'nde yayımlanmıştır. Roman, gazetenin sahibi Raşit Halid B.'nin Ödemiş, Aydın, Nazilli ve Muğla köylerinde derlediği bilgi ve beleğeler üzerine kurgulanmıştır. Dolayısıyla dönemin coğrafî, tarihî, sosyal ve kültürel özelliklerini yansıtmaktadır. Vak'a örgüsüyle ilgili bilgi, belge ve fotoğraflarla zenginleştirilen roman, tarih bilimi ve kurmaca türü edebî eserler için referans kaynak olarak kullanılmaktadır. Yazar Yaşar Kemal de Çakurcah Efe romanının ön sözünde Zeynel Besim Sun'un bu romanı için Çakırcalı üstüne yazılmış en ilginç kitaplardan bir olduğunu söylemektedir.

Romanda Çakıcı Mehmet Efe'nin soylu eşkıya tipolojisine uyan ve aykırı düşen birçok eylemi ve karakter özellikleri yer almaktadır. Romanın bazı bölümlerinde Çakıcı Mehmet Efe'nin askere silah çekmediği, cesur, yardımsever ve adaletli olduğu ile ilgili bilgiler yer alırken bazı bölümlerinde çocuk, kadın, asker demeden çok sayıda masum insanı acımasızca öldürdüğü, fidye karşılığında dağa adam kaçırdığı, posta soyduğu ve kaçakçılık yaptığı belirtilmektedir. Kurmaca olmakla birlikte ana malzemesini reel hayattan alan romanda, Çakıcı Mehmet Efe'yle ilgili farklı eylemlerin anlatılması döneme şahitlik eden Ege köylülerinin yaşadıkları farklı olaylardan kaynaklanmaktadır. Kurmacalardan ve reel kaynaklardan çıkan sonuçlara göre Ege köylülerinin bir kısmı Çakıcı Mehmet Efe'nin iyiliklerine, cesaretine ve adaletline şahit olmuşken kimileri de vahşiliğine, zulmüne ve adaletsizliklerine şahit olmuşlardır.

Yazar, Çakıcı Mehmet Efe çetesinin Osmanlı Devletinin otorite boşluğundan yararlanarak yasa dışı faaliyetlerde bulunduğunu; fakat yeni kurulan Türkiye Cumhuriyeti rejiminde bu tip çete faaliyetlerine fırsat verilmediğini belirtmektedir. Çünkü Türkiye Cumhuriyeti hükümeti memleketin her yerinde otoriteyi sağlamakta ve bu tip yasa dışı faaliyetleri engellemektedir. Yazarın vaka örgüsünün dışına çıkarak yaptığı bu tip yorumlar, dönemin kültür politikasından kaynaklanmaktadır.

Çakıcı Mehmet Efe'nin soylu bir eşkıya olup olmadığı tartışma konusudur. Soylu eşkıyaların en önemli özelliği adaletsiz hâkim güçlere karşı cesaretle mücadele etmeleridir. Devlet adamlarına, sermaye sahiplerine ve burjuva sınıfına isyan eden soylu eşkıyalar, kanun karşısında suçlu sayılırlar. Fakat emeği sömürülen halk tabakası nazarında ise itibarlıdırlar. Devlet otoritesinin olmadığı yerlerde ezilen halkın yanındadırlar, onları cesaretle korumaya çalışırlar. Haksızlığa uğrayan, yardıma muhtaç köylüler, soylu eşkıyaların gücüne sığınırlar. Zengin köy ağalarından alıp muhtaç köylülere dağıtmak, köylere yol, çeşme, köprü ve cami gibi imar işleri yaptırmak soylu eşkıyaların karakteristik özellikleridir. Ayrıca soylu eşkıyalar, acımasız ve zalim insanlardan intikam alırken merhametlidirler. Onlara işkence yapmazlar, öldürürken ölçülü davranırlar. Vatansever yanları baskın olan soylu eşkıyalar, izlerini takip eden asker ve zaptiyelere pusu kurup onları öldürmezler. Halk, soylu eşkıyaların askere silah çekmeyeceğine inanır. Çakıcı Mehmet Efe'yi yakından tanıma firsatı bulan Ege köylülerinin ifadelerinden yararlanarak kaleme alınan romana göre Çakıcı Mehmet Efe'nin dağa çıkıp çete kurma sebebi soylu eşkıya tipolojisiyle örtüşmektedir. Efe, baba katilini öldürerek dağa çıkmış ve kendisi gibi bir çete lideri olan babasının nüfuzunu kullanarak on beş yıl dağlarda kaçak olarak yaşamıştır. Çakıcı Efe, dağ köylerinde yaşadığı sürece fakir köylülere yardım eder, evlenmek isteyen köy gençlerini evlendirir, hastalara ilaç parası verir. Çakıcı'nın soylu eşkıya tipolojisiyle örtüşen bir başka özelliği de köylerde yol, köprü ve cami yaptırmasıdır. Ayrıca romanda Çakıcı'nın askere silah çekmediğine dair Ege'de yaygın bir inanışın olduğu belirtilir. Çakıcı'nın başta dağa çıkma sebebi olmak üzere yardımsever, şöhretli ve cesaretli yönü soylu eşkıya tipolojisiyle örtüşmektedir. Fakat soylu eşkıyaların vasıflarını ömrünün sonuna kadar sürdürdüğü tartışma konusudur. Zeynel Besim’in tespitlerine göre Çakıcı, fakir köylülere yardım eder, onlara iyiliklerde bulunur. Fakat yaptığı bu iyilikler ve yardımlar stratejik 
amaçlıdır. Zaptiyelerden ve askerlerden kaçan Çakıcı Mehmet Efe, halka yardım ettikçe köylülerin desteğini alır ve bölgenin en etkili eşkıya çetesini kurar. Ancak bir eşkıya tarafından çıkar amacı gözetmek suretiyle diğer ihtiyaç sahiplerine yapılan destek söz konusuysa, soylu eşkıyalıktan söz etmek mümkün değildir. Örneğin zenginden alıp fakire dağıtan eşkıya, bunu bir sonraki aşamada kendisine yardım ve yataklık için veya istihbarat ağı oluşturmak için yapıyorsa, burada soylu eşkıyalıktan değil; bir çıkar ilişkisinden söz edilebilir. Çünkü bu tür çıkar amaçlı yardım etik ve ahlak dışı bir eylem olarak kabul edilir ve rüşvet olur. Çakıcı Mehmet Efe'nin kaçak olarak yaşadığı köylerde sosyal ilişkileri çıkar amaçlı olmuştur. Bu sebeple Çakıcı Mehmet Efe'nin sosyal eşkıya tipolojisine uygun özellikler taşıdığı söylenemez.

Romanda Çakıcı'nın içinde asker, çocuk ve kadınların da bulunduğu çok sayıda Ege köylüsünü öldürdüğü, fidye almak için dağa adam çıkardığı, köylülere işkence ettiği, haydutluk yaptığı anlatılır. Ayrıca Çakıcı Mehmet Efe'nin düşmanlarından intikam alırken son derece acımasız ve merhametsiz olduğu belirtilir. Kurmacaya göre acımasız yönü baskın olan Çakıcı Mehmet Efe, kendi adını kullanarak kız kaçıran dokuz çete üyesini diri diri ateşe atar. Romanda Çakıcı'nın kendisine rakip olarak gördüğü zeybeğini uykudayken öldürdüğü ve emirlerine itaat etmeyen köylülerin evlerini bastıktan sonra çocuklarını dağa çıkardığı da anlatılır.

Çakıcı Mehmet Efe'nin soylu eşkıya tipolojisine aykırı düşen eylemleri reel tarihî kaynaklarla ve Osmanlı arşivlerinde bulunan bilgi ve belgelerle örtüşmektedir. Kaynaklara göre de Çakıcı, fidye almak için zengin köylüleri dağa çıkarır, fabrika yakar ve postane soyar. Tütün kaçakçılığı, hükümet potasını soyma gibi yasa dışı eylemleri olan Çakıcı hakkında yakalama ve öldürme kararı çıkarılır. Romanın sonunda anlatıldığına göre Çakıcı Efe, hükümet zaptiyelerinden kaçarken yanlışlıkla bir kızanı tarafından vurularak öldürülür. Çakıcı Mehmet Efe'nin ölüm haberine kimse inanmaz. Hükümet yetkilileri, halkı Çakıcı Mehmet Efe'nin ölümüne inandırmak ve kanun kaçaklarının kötü sonunu halka göstermek için Çakıcı Mehmet Efe'nin cesedini Nazilli hükümet konağının kapısına asar. Hükümet yetkilileri, cesedi, Nazilli mezarlığına gömmek ister. Fakat Nazilli halkının itirazı üzerine Çakıcı Mehmet Efe'nin cesedi Nazilli, Ödemiş, Alaşehir yolu üzerinde bir çukura gömülür. Çakıcı Mehmet Efe'nin trajik sonu, romanda ve Sabri Yetkin'in Ege'de Eşkıyalar kitabında aynı şekilde anlatılmaktadır. Her iki kaynaktan çıan sonuca göre Çakıcı Mehmet Efe'nin ölüm haberi halk arasında memnuniyetle karşılanır ve Çakıcı Mehmet Efe'nin cesedine adi bir eşkıya muamelesi yapılır.

Bütün bu değerlendirmeler, Cumhuriyet tarihinden bu yana Türk romanlarında, tiyatrolarında ve sinemalarında soylu eşkıya tipolojisiyle tanıtılmaya çalışılan Çakıcı Mehmet Efe'nin aslında adi eşkıya tipolojisine yakın bir karakter olduğunu göstermektedir.

Kültür Bakanlığı tiyatro ve dans toplulukları ve bazı belediyelerin kültür müdürlükleri de her yıl Çakıcı Mehmet Efe hakkında müzikli tiyatro etkinlikleri düzenlemektedir. Çakıcı Mehmet Efe'nin resmî kurum ve kuruluşların etkinliklerinde bir tema olarak kabul edilmesi tartışma konusudur. Bu etkinliklerde kullanılan kurmaca metinlerin reel kaynaklarla karşılaştııllarak yeniden düzenlenmesi gerekmektedir. 


\section{Kaynakça}

Arusan, (Taranç) Berrak (1988), Ege Bölgesinde Yaşayan Halk Müziği Ezgileri, Zeybekler ve Elli Altı Ezginin Çeşitli Yönleriyle Kataloglanması. Ege Üniversitesi Devlet Türk Musikisi Konservatuvarı Yayınları. İzmir.

Çelik, Yakup (2002) “Tarih ve Tarihî Roman Arasındaki İlişki Tarihî Romanda Kişiler” Bilig, S: 22, ss.49-68.

Diker, Ahmet (2016), Hayde Bre Efeler, Duvar Yayınevi, İzmir.

Dural, Halil (1999), Bize Derler Çakırca 19. ve 2o. Yüzyılda Ege'de Efeler, Tarih Vakfı Yurt Yayınları, İstanbul.

Ege 9 Eylül Gazetesi (6.11.2016). http://www.dokuzeylulgazetesi.com/haber/ege-gosteri-sanatlariefelerin-destanini-yazdi-35980.html (09.05.2018)

Ekici, Metin, "Kafkaslar, Anadolu ve Balkanlarda Kaçak, Efe ve Haiduk Hikâyelerinin Yapısal Bir İncelemesi”,https://www.academia.edu/5626059/Prof._Dr._Metin_Ekici_Ka\%C3\%A7ak_Efe_ ve_Haiduk_Hik\%C3\%A2yelerinin_Yap\%C4\%B1sal_Bir_\%C4\%Boncelemesi), (o9.06.2018)

Gözütok, Türkan (2011), "Eşkiyalık Ve Çakırcalı Mehmet Efe’nin Türk Edebiyatına İzdüşümü”, Türkbilig Dergisi, S:21, ss.49- 72.

Uyanık, Ercan (2014), “Çakırcalı Mehmet Efe'nin Kronolojisi”, Ege Defteri, S:4, ss. 3-43.

Hobsbawm, Eric J. (1997), Eşkıyalar, (Çev.) Nejdet Hasgül, Orhan Akalın, Avesta Yayınlar, İstanbul.

Kemal, Yaşar, (2017), Çakurcalı Efe, Yapı Kredi Yayınları, İstanbul.

Lee, Nan A. (2003), "Köroğlu Destanı ve Honggildong Hikâyesi Üzerine Benzerlikler ve Farklılıklar Açısından Karşılaştırmalı Bir Çalışma”. Türkoloji Dergisi S:2, ss. 131-144.

Moran, Berna (2012) Türk Romanına Eleştirel Bir Bakış 2, İletişim Yayınları, İstanbul.

Özbilgin, Mehmet Öcal (2003), Zeybeklik Kurumu ve Zeybek Oyunları, Ege Üniversitesi Sosyal Bilimler Enstitüsü, (Yayınlanmamış Doktora Tezi), İzmir.

Özden, M. Yaşar ve Durdu, Levent (2016), Nitel Araştırma Yöntemleri, Anı Yayıncılık, Ankara.

Rousseau, Jean Jacques (2010), Emile, (Çev.) Yaşar Avunç, Türkiye İş Bankası Kültür Yayınları, İstanbul.

Rousseau, Jean Jacques (2006), İnsanlar Arasındaki Eşitsizliğin Kaynağı, (Çev.) R. Nuri İleri, Say Yayınları, İstanbul.

Stevick, Philip (2010), Roman Teorisi, (Çev.) Sevim Kantarcıŏlu, Akçă̆ Yayınları, Ankara.

Sun, Zeynel Besim (1934), Çakıcı Efe, İzmir Ticaret Postası Gazetesi, İzmir.

Şapolyo, Enver Behnan (1991), "Efe, Zeybek, Kızanların Yaşayışları ve Adetleri”. Efeler (Kökenleri, Eylemleri, Töreleri, Dansları, Giysileri). (Haz.) Ersal Yavi Aydın: Aydın Valiliği İl Özel İdaresi Yay., No. 3, Aydın.

Türkçe Sözlük (2011), TDK Yayınları. Ankara.

Üsküp, Şeref (1992), Milli Mücadele’de Efeler, Hür Efe Matbaası, İzmir.

Veren, Ergün (2014), "Efelik Müessesesinde Zeybekliğe Terfi Etme ve Yemin Töreni," Acca Turcıca Çevrimiçi Tematik Türkoloji Bilgisi, S: 2, ss. 1-9.

Yetkin, Sabri (1996), Ege’de Eşkıyalar, Tarih Vakfı Yurt Yayınları, İstanbul. 